The Retrenchment Hypothesis and the Extension of the Franchise in England and Wales

Toke S. Aidt, Martin Daunton and Jayasri Dutta

April 2008

CWPE 0818 


\title{
The Retrenchment Hypothesis and the Extension of the Franchise in England and Wales*
}

\author{
Toke S. Aidt ${ }^{\dagger}$ Martin Daunton ${ }^{\ddagger}$ and Jayasri Dutta ${ }^{\S}$
}

April 29, 2008

\begin{abstract}
Does local democracy help or hinder the solution of collective action problems? We study this question in the context of public spending on health-related urban amenities in a panel of 75 municipal boroughs in England and Wales in 1868, 1871 and 1886. We find evidence of a U-shaped relationship between spending on urban amenities and the extension of the local voting franchise. We argue that this retrenchment effect arose because middle class taxpayers were unwilling to pay the cost of poor sanitation and the urban elites, elected on a narrow franchise, were instrumental for sanitary improvements. Our model of taxpayer democracy suggests that the retrenchment effect is related to forced enfranchisement of the middle class through nation-wide reforms.

Keywords: Voting franchise, retrenchment, local public goods, sanitation.

JEL Classification: D62; D78; H71; N930.

*This research was supported by the ESRC (grant no. L138251006). We have benefited from comments by Simon Szreter, Stanley Engerman, Pramila Krishnan, Robert Millward, Arye Hillman, Vania Sena, John Maloney and seminar participants at Birmingham, Cambridge, Edinburgh, Exeter, Oxford, BarIlan, Université Libre de Bruxelles, and Southampton. We would like to thank Pedro Ramos Pinto, K.L. Rakowsky, Fathima Himaz and Elena Loukoianova for research assistance.

†Corresponding author: Faculty of Economics, University of Cambridge, CB3 9DD Cambridge, U.K. E-mail: toke.aidt@econ.cam.ac.uk.

${ }^{\ddagger}$ Faculty of History, University of Cambridge, Email: mjd42@cam.ac.uk.

$\S$ Department of Economics, University of Birmingham. E-mail: J.dutta@econ.bham.ac.uk.
\end{abstract}


"The principle of constructive rating ..... has had the effect of throwing a great deal of power in the hands of the smaller voters in urban districts, which power, I am sorry to say, they do not exercise upon very enlightened principles; and unless there was the counterpose of rural voting for the benefit of the owners of property, I think that sanitary improvements would very soon be brought to a stand still in many urban districts." (The Select Committee on the Poor Law Guardians of 1878 as quoted by Keith-Lucas, 1952, p. 70).

\section{Introduction}

Does local democracy help or hinder the solution of collective action problems? How does the allocation of voting rights in local elections matter for provision of local public goods? Can the extension of the voting franchise be a source of retrenchment rather than of expansion of public spending? These century old questions are still highly relevant in today's world. ${ }^{1}$ This paper provides some new answers by taking a historical perspective. We study theoretically and econometrically the role of local democracy in solving collective action problems in mid-Victorian cities in England and Wales. This context provides a promising testing ground for three related reasons. Firstly, mid-Victorian cities urgently needed to invest in urban infrastructure, sanitation and other health-related urban amenities to make up for the under-investment in the urban economy earlier in the century. ${ }^{2}$ Secondly, this challenge fell almost exclusively on local government. Beginning in the late 1860s, local authorities across England and Wales were investing in urban amenities, at first in clean water and later on, in sewers, local transportation, and gas works, on an unprecedented scale. ${ }^{3}$ Thirdly, these improvements did not happen over-night, nor did they happen at the same time in all cities. Much depended on who had gained control of the Municipal Corporation (borough council) which by 1870 had emerged as the main provider of urban amenities in many boroughs. This, in turn, depended on the allocation

\footnotetext{
${ }^{1}$ See Santos (1998) and Bardhan (2000) for a discussion of the merits of decentralization of provision of public goods and World Bank (2000) and Chattopadhyay and Duflo (2004) for a discussion of the merits of creating opportunities for participation in local politics of disenfranchised groups.

${ }^{2}$ See Williamson (1990, chapter 10) or Szreter (1997) for a discussion of under-investment in local public goods before 1860. Szreter and Mooney (1998) show that despite rising real wages, life expectancy at birth was higher in many urban areas in 1821 than in 1871 thus testifying to the deteriorating urban environment.

${ }^{3}$ See Millward (2001, p. 315) and Bell and Millward (1998).
} 
of voting rights within the borough, i.e., on the extension of the franchise governing local elections.

Economic historians, such as Hennock (1963, 1970) and Szreter (1988, 1997), have emphasized the role of political factors in understanding why some cities managed to find solutions to the public health crisis more effectively and faster than others. They identify the power struggle between "economists" and "sanitarists" as a key factor. "Sanitarists" argued for public investments in health related public amenities, whereas "economists" wanted to economize on the level of city spending. ${ }^{4}$ The outcome of this struggle was, in turn, related to the extension of the voting franchise which varied a lot from borough to borough. This historical narrative has an important testable implication that we call the retrenchment hypothesis. It suggests that spending on urban amenities was relatively low in boroughs with a moderately extended franchise because this allowed lower middle class "economists" to control the boroughs. In contrast, in boroughs in which the franchise put the urban elite and the "sanitarists" in charge action was taken to solve the underinvestment problem.

The narrative, however, leaves two questions open. First, why did the allocation of voting rights differ from borough to borough? Second, does an extension of the franchise necessarily cause retrenchment? To gain insights into these questions, we develop a theory of taxpayer democracy. ${ }^{5}$ The theory provides a simple, but compelling, explanation for the uneven extension of the franchise across cities and shows that the retrenchment hypothesis is more likely to hold in cities with high wealth inequality and a small middle class. We also show that enfranchisement of the middle class can be a Pareto improvement, but only if spending on local public goods increases as a consequence. The theory, therefore, implies that the source of middle class retrenchment (i.e., a fall in spending) is

\footnotetext{
${ }^{4}$ See also Fraser (1976), Offer (1981), Wohl (1983) and Daunton (2001, chapter 9).

${ }^{5}$ Recent research on the extension of the voting franchise has stressed the threat of revolution (Acemoglu and Robinson, 2001, Conley and Temini, 2001), conflict within the elite about assignment of rents (Lizzeri and Persico, 2004), gradual alienation of the disenfranchised (Justman and Gradstein, 1999), and constitutional exchange (Congleton, 2004) as four reasons why voting rights were granted in Western Europe during the nineteenth century. Our theory adds to this literature by modelling democratization as an exchange of political influence for tax revenues. Although this approach in itself cannot explain why nation-wide franchise reforms, such as the Municipal Franchise Act of 1869, were agreed, it does provide useful insights into the sources of spatial variation in the extension of the franchise across boroughs.
} 
forced enfranchisement of the middle class occurring through nation-wide reforms. These results allow us to use the theory constructively to develop a proper empirical test of the retrenchment hypothesis.

The main contribution of the paper is an empirical test of the retrenchment hypothesis. We make use of a new panel data set on spending on urban amenities by (up to) 75 Municipal Corporations in England and Wales in 1868, 1871 and 1886. Our results support the retrenchment hypothesis. We find that democratization would have led to a reduction in spending on urban amenities in boroughs where less than 40 per cent of the adult male population could vote, and to an expansion in boroughs with a wider franchise than that. The 40 per cent turning point is approximately in the middle of the sample.

These results suggest that "capture" by local elites, which is generally considered a cost of decentralized provision of public goods (see, e.g., Bardhan and Mookherjee, 2000), can be a force of improvement in situations, as in nineteenth century urban England and Wales, where the private interest of the local elite is aligned with general development goals. On the other hand, our results also show that local democratic institutions, even when they operate well and provide accountability and voice as intended, can be a force of retrenchment when the power falls into the hands of groups that do not wish to spend on public goods. In fact, this can be seen as a counter-example to Director's law, as public expenditure on urban amenities did not primarily benefit the middle class and expansion of local government spending was driven mainly by the urban elite, not by the middle class. ${ }^{6}$ Finally, our results challenge the view that enfranchisement of citizens with below-average income must lead to an expansion of public spending and show that it is often wrong.

The paper is organized as follows. In section 2, we discuss the institutional background. In section 3, we introduce the retrenchment hypothesis. In section 4, we develop the model. In section 5 , we discuss the data, our empirical strategy and present the results. In section 6, we conclude. Discussion of the data material and sources can be found in the Appendix which also contains some proofs. A separate Appendix with a detailed discuss of the robustness of the theory and of the empirical results can be found at the end of the paper.

\footnotetext{
${ }^{6}$ Stigler (1970) in his classical discussion of Director's Law was, of course, well aware that the politics and the public finances of the nineteenth century often did not lead to redistribution to the middle class.
} 


\section{Institutional Background}

During the nineteenth century, local government in urban England and Wales consisted of a range of different elected or appointed authorities ${ }^{7}$, with overlapping boundaries, and different rules for election or appointment of their members. ${ }^{8}$ For the purpose of this study, the most important of these local government authorities is the Municipal Corporation. During the 1860s, the Corporations became the main (public) provider of public health and sanitation in the boroughs. It was up to them to deal with the challenge of a deteriorating urban environment and eventually to take action to improve the situation.

\subsection{Taxpayer Democracy}

The Corporations were governed by the borough councils. The elected councillors were chosen in yearly elections. The franchise that defined who were eligible to vote was laid down in the Municipal Corporation Act of 1835 and applied to all boroughs. The franchise was firmly based on the principle of "no taxation without representation." ${ }^{9}$ In other words, an occupier of rated property, who duly paid the local property tax (called the rate), was, with some qualifications, entitled to register for the vote, and, conversely, residents whose properties were not taxed were automatically disenfranchised. Brian Keith-Lucas summarizes the precise eligibility requirements as follows

"Eligible as a voter was every man who was an inhabitant householder within a borough or within seven miles thereof and who had occupied any house, warehouse, counting house or shop within the borough for the previous two and a half years, provided he had been rated for the whole of that period and had paid the rates, and was duly enrolled on the Burgess Roll. Those, who, within the previous twelve months, had received parochial relief or other alms

\footnotetext{
${ }^{7}$ Examples include the Poor Law Guardians (poor relief), School Boards (primary education), Local Boards of Health (health and sanitation), Local Improvement Commissions (sewers, water etc.), Highway Commissions, and the Municipal Corporations.

${ }^{8}$ Smellie (1946, chapters 2 and 3) provides a detailed description of the structure.

${ }^{9}$ Individuals, whether they paid the rate or not, were liable to pay indirect and sometime also direct (income) taxes to the central government. Thus, the principle of "no taxation without representation" applied only to taxation at the local level where the rate was the only tax that could be levied.
} 
[under the Poor Laws] were excluded, and provision was made to enable a tenant, in cases where the landlord was liable for the rate, to pay them himself and so quality for the franchise." Keith-Lucas (1952, p. 53, italic added).

[Table 1: The extension of the voting franchise for the Municipal Corporations in 1852, 1865, 1871 and 1884].

Only local taxpayers who owned personal property or land worth more than a certain amount were eligible to stand for election (Keith-Lucas, 1952, p. 228). This effectively excluded the poorer taxpayers from seeking election. Moreover, councillors were unpaid and were burdened with significant administrative duties, and meetings were held during working hours. This, in practice, continued to make it prohibitively costly for many eligible (working class) candidates to seek election, even after the Municipal Corporation Act of 1882 allowed any enfranchised man to run for election. ${ }^{10}$

The British Parliamentary Papers contain quantitative information on the number of registered voters in 1852, 1865, 1871 and $1884 .{ }^{11}$ We measure the extension of the franchise as the number of registered voters relative to the adult male population of the borough. ${ }^{12}$ These data are shown in Table 1 for a sample of about 75 boroughs. In 1852, only 29 per cent of the adult male population was registered to vote. Through a sequence of acts of Parliament over the next 50 years, the franchise was gradually extended. The substantial increase in the proportion of enfranchised individuals between 1865 and 1871 can be attributed to the Municipal Franchise Act of 1869. This act reduced the residence requirement from two and a half years to one year, and allowed occupiers of "other buildings" including cottages to qualify for the vote. The Assessed Rates Act of 1869 also contributed to the extension of the local franchise (see below). Szreter (1997, p. 710) suggests these reforms enfranchised a substantial fraction of working-class men. The

\footnotetext{
${ }^{10}$ Party politics was limited by the fact that party members stood for election as individuals, but did play a role in some boroughs (Fraser, 1976, chapter 6; Doyle, 2001).

${ }^{11}$ This most likely underestimates the true number of eligible voters.

${ }^{12}$ This base is chosen because the electorate was primary recruited from among the male population. However, it may be noted that from 1869 onwards unmarried or widowed women were entitled to vote in local elections.
} 
extension continued throughout the 1870s and into the 1880s with the Parliamentary and Municipal Registration Act of 1878 and the Municipal Corporation Act of 1882. By 1884, 64.5 per cent of the adult male population was on the electoral roll.

The data recorded in Table 1 show another important fact about local democracy in mid-Victorian England and Wales: the franchise was unevenly extended across boroughs. For example, the "most democratic" borough in 1865 had 82 per cent of the adult male population on the roll, while the "least democratic" borough had only 11.4 per cent. By 1884, the spread had narrowed somewhat, but was still substantial. ${ }^{13}$ Matthew et al. (1976) argue convincingly that the inter-borough variation in the extension of the franchise reflected exclusion by social class. Boroughs with a narrow franchise effectively excluded working class men, and boroughs with a very narrow franchise, in addition, excluded large portions of the middle class. This was achieved through variations in the fraction of properties in the borough that was, in fact, taxed, but also in two more subtle ways. First, an important question was whether tenants who paid the local property tax indirectly through their landlord - a practice known as compounding - were entitled to the vote or not. ${ }^{14}$ Compounding was first introduced in 1850, but the law was unclear and practises differed substantially from borough to borough. For example, an attempt to put "compounders" on the electoral roll in 1864 in Birmingham was declared illegal by the courts (Hennock, 1973, p. 11). After the Representation of the People Act of 1867 disallowed the use of compounding, compounding was reintroduction with the Assessed Rates Act of 1869. This, in principle, enfranchised indirect ratepayers. Nevertheless, their right to the vote continued to be disputed in the courts. The issue was not settled until 1878 with the Parliamentary and Municipal Registration Act and finally by a court case in 1881. ${ }^{15}$ Second, under the 1835 franchise, a householder was understood to mean an

\footnotetext{
${ }^{13}$ Since the standard deviation is roughly constant and the average increases over time, it is clear that the coefficient of variation is lower in 1884 than in 1852.

${ }^{14}$ The system was based on the principle that the tax collector accepted an amount less than the whole tax in return for the landlord, and not the tenant, becoming responsible for the payment. This was a cost-effective way of collecting taxes from low-value properties.

${ }^{15}$ Even in boroughs where the principle was accepted, the practical issue of whose name appeared in the rate book persisted. In cases where the tenant's name and not the landlord's appeared in the rate book, the tenant was mostly regarded as being entitled to vote. In cases where the landlord's name appeared in the rate book rather than the tenant's, it was much harder for the tenant to get enfranchised. He would
} 
individual who occupied a separate dwelling. This effectively disenfranchised individuals who shared a house with others. It was not until 1878 that it was firmly established that tenants living in shared accommodation could qualify individually for the vote. Until then, depending on the extent of crowding in particular boroughs and the attitude of the officials who draw up the electoral lists from the rate books, a large but varying number of poor taxpayers was disenfranchised simply because they happened to share a (rated) house with others. The ambiguities surrounding the status of occupiers of shared accommodation and indirect taxpayers arguably biased the franchise against the working class. ${ }^{16}$

\subsection{Self-governance and Fiscal Autonomy}

As initially envisaged by the Municipal Corporation Act of 1835, the activities of the Corporations were confined to the holding of property, to the regulation of markets and harbours, to the establishment of policing and lighting systems, and to the making of by-laws. By 1870, however, many Corporations had became the main provider of urban infrastructure, sanitation and other health-related urban amenities. ${ }^{17}$ The responsibility for drainage, sewage, treatment of waste, paving and street-widening, construction of cemeteries, reliable supply of clean water etc. had gradually came under the jurisdiction of the Corporations, either by application to Parliament or by adoption of permissive general legislation. ${ }^{18}$ Under the Public Health Act of 1848, towns and districts could, for example, establish a Local Board of Health. Many Corporations did so and from 1872 acted as Urban Sanitary Authorities. ${ }^{19}$ Accordingly, within the boundaries defined by statuary

have to seek permission to substitute his own name for that of the landlord every six months.

${ }^{16}$ David and Tanner (1996) emphasize differences in administrative efficiency as another source of variation in who, in practice, got on the Rolls in their study of who qualified to vote for the Parliament in the late 1860s. Similar problems almost surely arose in relation to registration for local elections.

${ }^{17}$ Millward and Sheard (1995) estimate that about 90 per cent of all investment in infrastructure, including investments in sanitation, in England and Wales from 1870 to 1914 were undertaken by local authorities, including the Corporations, and financed out of local resources.

${ }^{18}$ The Corporations were never responsible for three key areas: main roads, primary education and poor relief, which fell under the Highway Authority, the School Board and the Guardians of the Poor, respectively.

${ }^{19}$ The Public Health Act of 1848 permitted a minority of ratepayers - $10 \%$ - to petition the General Board to implement the act and set up a Local Board of Health. The Corporation could, if it wished, implement the act itself or a separate Local Board of Health might be established. The Corporation, if acting, then had unprecedented powers to borrow, with the consent of the General Board, up to a year's assessable value and to mortgage the rates for 30 years for purposes of improving sanitation and health. 
law and the local tax base, the Corporations had significant freedom to provide more services than required and in better quality. In short, progressive Corporations looking to undertake new activities could generally find ways of doing so but had to shoulder the cost themselves (Davis, 2001, p. 264).

The Local Taxation Returns contain detailed information on the finances of the Corporations, starting in the late 1860s. From this source, we construct two measures of the Corporations' spending on sanitation and other health-related urban amenities. First, we identify expenditure categories that clearly reflect a sanitary function. This includes spending on sewage, water, streets paving and other similar public works. This measures spending on urban amenities directly, but does not distinguish between current and capital expenditures. ${ }^{20}$ Second, the Corporations could for investment purposes borrow funds from the capital markets. While many of these were spend on urban amenities, it cannot be established from the Local Taxation Returns how large this component was. Information on borrowed funds, therefore, gives an imperfect estimate of capital expenditures on urban amenities only. ${ }^{21}$

We shall use spending on urban amenities and borrowed funds as two alternative proxies for the Corporations' involvement in the provision of health-related amenities. We focus on a sample of about 75 Corporations in 1868, 1871, 1875, 1886 and 1888. The Corporations represent a mixture of industrial cities and market towns. We are careful only to include Corporations that controlled the Local Board of Health from 1868 onwards. This ensures that the selected Corporations were the main provider of public health in their borough and that decisions to spend on these services were governed by the franchise rules laid down for the Corporations. ${ }^{22}$

The Public Health Act of 1858 made it harder to establish a Local Board, by requiring the approval at a ratepayers' meeting. The Public Health Act of 1872 replaced the Local Board with the Urban Sanitary Authority. This could be, and often was, run by the Corporations. The Public Health Act of 1875 finally required the Corporations to take full charge of health matters in their borough.

${ }^{20}$ The Local Taxation Returns do not record capital and current expenditures separately until after 1882.

${ }^{21}$ It is not clear if this is an over- or underestimate. On the one hand, capital expenditures could be financed out of current revenue. On the other hand, borrowed funds might have been used for other purposes than sanitary improvements.

${ }^{22}$ Where the Corporations did not act as the Local Board, the representatives on the board were elected on a graduated franchise which, in contrast to the franchise for the Corporations, gave more votes to 
Table 2 records average spending on urban amenities and borrowed funds, either per capita or in percentage of total spending by year. About 50 per cent of the budget was, on average, being spent on urban amenities while borrowed funds contributed 15-18 per cent of income. However, in per capita terms spending on urban amenities more than doubled during the 1870s. This reflects in part the response to mounting pollution and poor public sanitation. Most strikingly, perhaps, is the fact that the inter-borough variation is persistently high. Some Corporations spend a lot more than others and started doing so much earlier than others. Although it is not possible to give a detailed breakdown of spending categories, Bell and Millward (1998) argue that the lion's share of sanitary investments before 1880 was related to water supply. This observation is important. Supply of clean water, of course, serves an important sanitary purpose ${ }^{23}$, but water is also a component of many manufacturing processes. The motivation behind the investment boom in water supply in the 1870s might therefore partially have been due to health concerns and partially have been driven by commercial interest.

[Table 2: Average spending on urban amenities and borrowed funds, 1868-1888.].

The local tax base was rateable property. ${ }^{24}$ These local property taxes constituted between 50 and 60 per cent of total revenues for the Corporations. ${ }^{25}$ In relation to profits, the property tax fell heavily on small, retail establishments and workshops - owned by the lower-middle class. For house occupiers, who paid the tax directly, it was clearly regressive in tendency because, though rich people generally occupied more valuable property, they did not do so proportionally to income (Waller, 1983, chapter 6 ). ${ }^{26}$ There were, of occupiers of more valuable properties.

${ }^{23}$ Insofar as these investments in clean water, as it seems to have been the case, were unaccompanied by sufficient investments in complementary services such as street paving and sewer construction, the reduction in water-based diseases would be limited because large quantities of contaminated water could accumulate in ashpits and cesspools. Thus, the health-related benefits of these investments might initially have been limited (see Bell and Millward, 1998).

${ }^{24}$ All movable wealth, the content of the property as well as income, profits and losses from trade and employment were not taxable at the local level.

${ }^{25}$ See Daunton (2001, chapter 9) for more details.

${ }^{26}$ Until 1925, properties were rated by the 640 Boards of Guardians in 14330 rating areas. Lack of uniformity across rating areas and lack of professional standards were widespread, and "the assessments were riddled with antiquated and inconsistent procedures and more than a hint of favoritism, particularly 
course, other sources of income for the Corporations than the local property taxes. In the late 1870 s and 1880s, for example, profits from municipal water and gas works and tramways became an important source of income in boroughs such as Birmingham, Leeds and Manchester, which could not rely on incomes from estates as in, for example, Liverpool, Hull, Southampton, and Bristol (Millward, 2001). On the other hand, central government grants never contributed more than five per cent of the annual budget, and the grants were always earmarked for specific purposes, such as police uniforms.

\section{The Retrenchment Hypothesis}

What accounts for the large differences in spending on urban amenities per capita across boroughs and across time? Economic and social historians, such as Hennock $(1963,1970)$ and Szreter $(1988,1997)$, have emphasized political factors. ${ }^{27}$ In his classical comparative study of Birmingham and Leeds, Hennock (1973), for example, identifies the power struggle between "economists" and "sanitarists" as a major source of variation in spending on urban amenities during the second half of the nineteenth century. The "economists" represented the interests of middle class ratepayers (shopkeepers, house landlords, and small manufacturers). They did not wish to pay the cost of poor sanitation as the incidence of the property tax fell particularly hard on them. The "sanitarists", on the other hand, advocated municipal involvement in the provision of public health (employment of medical officers, building regulation, closure of wells and pits, etc.) and other sanitary improvements (sewers, clean water, slum clearance, street widening etc.). These were recruited mainly among the urban elite (wealthy capitalists, big manufacturers and professionals). This group often stood to benefit disproportionately from improvements in the urban environment. In many cases, it was only when local businessmen could see a commercial advantage of spending on urban amenities that action was taken (Szreter, 1997, p. 708). A leading example is reliable water supply which had substantial commercial value for many industries. More generally, local manufacturers benefited commercially from having access

under-assessment of wealthy districts." (Waller, 1983 p. 258).

${ }^{27}$ See also Fraser (1976), Offer (1981), and Daunton (2001, chapter 9). 
to a more healthy workforce and better urban infrastructure (e.g., tramways, paved streets etc.). The balance of power between these two groups was decisive for both the scale and the timing of investments in public health. Importantly, in whose favor the balance of power tipped, in turn, depended on the extension of the voting franchise.

Under a restricted franchise, the urban elite could control the councils, and show its willingness to spend on urban amenities, in particular when it made commercial sense to do so. Under a moderately extended franchise, middle class shopkeepers, small manufacturers and landlords, often organized in ratepayers' associations, could control the councils. With their concern for economy, they kept spending on urban amenities down. Under a wide franchise, working class men constituted a significant fraction of the electorate. As under a narrow franchise, the result was high spending on urban amenities, either because a cross class alliance between workers and the urban elite brought the "sanitarists" back into power ${ }^{28}$ or simply because of the enlarged tax base that allowed the cost of urban amenities to be spread across more taxpayers. This historical narrative has an important testable implication which we call the retrenchment hypothesis: the relationship between spending on local public goods (urban amenities) and the extension of the voting franchise is U-shaped.

Taxpayer retrenchment was, therefore, intrinsically related to the extension of the franchise, which, in turn, was determined by a mixture of local and national factors. On the one hand, the franchise was constituted rather than passively granted and could be systematically manipulated locally by decisions related to property rating, to the treatment of compounders and individuals living in shared accommodation, or to the procedures for registration. These factors are likely to have contributed to the inter-borough variation in the extension of the franchise. The size of the electorate therefore becomes a function of local conditions that might also have affected spending decisions directly. On the other hand, nation-wide reforms, such as the Municipal Franchise Act of 1869 and the Municipal Corporation Act of 1882, contributed to the enfranchisement of the lower middle and working class in the 1870 s and 1880 s. These reforms are unlikely to have been affected

\footnotetext{
${ }^{28}$ Working class candidates were effectively excluded from standing for election and so, the working class voters needed someone to represent their interests in the council.
} 
directly by the politics of any particular borough. They can therefore be viewed as natural experiments.

\section{A Model of Taxpayer Democracy}

In this section, we present a model of taxpayer democracy. The theory generates predictions that are useful in developing a proper test of the retrenchment hypothesis, and we view it as a necessary stepping stone for the empirical analysis to follow. The model is designed with the specific institutional framework of mid-Victorian Britain in mind. The critical assumption is that the urban elite, for a given tax base, wants to spend more on local public goods than the middle class. In the model this is guaranteed by a combination of three assumptions which are descriptive of mid-Victorian cities. The three assumptions are: i) the (marginal) benefits of local public goods are proportional to capital endowments, ii) capital endowments are unequally distributed, and iii) the property tax is regressive. Other combinations of assumptions can, however, be devised to generate similar results, and we believe that the main results (reported in Propositions 1 to 3 ) are valid more generally.

\subsection{The Economy}

We consider a city populated by wealthy capitalists $(H)$, middle class capitalists $(M)$ and workers $(L)$. Each wealthy capitalist is endowed with more capital $(k)$ than a middle class capitalist: $k_{H}>k_{M}$. Workers are endowed with one unit of labour and no capital. Labour is supplied inelastically to a competitive labour market. Each group is homogenous and its size is $n_{i}$ with $i \in\{H, M, L\}$. We assume that $n_{M}>n_{H}$ and that $n_{L}+n_{H}>n_{M}$.

Capitalists of type $i$ employ their capital endowment $k_{i}$ and hired labour $l_{i}$ to produce the consumption good $Y_{i}$. The production technology is

$$
Y_{i}=A(g) \ell_{i}^{\alpha} k_{i}^{1-\alpha} ; 0<\alpha<1
$$

where $A($.$) represents total factor productivity and g$ is a local public good. Output is sold in the national market, at price $p_{Y}=1$. The demand for labour from a capitalist 
of type $i$ is $\ell_{i}=k_{i}\left(\frac{\alpha A(g)}{w}\right)^{\frac{1}{1-\alpha}}$. The market clearing wage is $w^{*}(g)=A(g) z$, where $z=$ $\alpha\left(\frac{n_{M} k_{M}+n_{H} k_{H}}{n_{L}}\right)^{1-\alpha}$. Profits earned by each capitalist of type $i$ are $\pi_{i}^{*}(g)=A(g) k_{i} x$, where $x=(1-\alpha)\left(\frac{n_{L}}{n_{M} k_{M}+n_{H} k_{H}}\right)^{\alpha}$.

Improvements in the health environment of the city is akin to a pure public good. Although these improvements are created by services, such as clean water, sewage facilities etc., which to some extend are excludable, the general health benefits are non-depletable and non-excludable. To be concrete, we assume that the urban economy becomes more productive when the health environment improves and total factor productivity, $A(g)$, is a strictly increasing and concave function of $g$. Moreover, local public goods are essential for production, i.e., $A(0)=0$, and $A(g)$ satisfies the Inada conditions. An important implication of this is that profits and wages are increasing in spending on local public goods. Wealthy capitalists, however, benefit more from extra spending than middle class capitalists. This is because the (marginal) benefit is proportional to capital endowments. We assume that workers are poorer than middle class capitalists $\left(z<x k_{M}\right)$. Consequently, they benefit the least from extra spending. ${ }^{29}$ Local public goods are financed out of local property taxes.

All citizens have quasi-linear Cobb-Douglas preferences defined over the consumption good $y$ and housing $h$ :

$$
u_{i}=y_{i}+\beta^{-1} h_{i}^{\beta} \text { with } \beta \in(0,1) .
$$

Capitalists are endowed with two units of housing; workers with none. Each capitalist consumes one unit of housing privately (their own house) and, if applicable, pay the tax levied on it $\left(\tau_{i}\right)$ directly. The other unit is supplied to a competitive market for rental accommodation. Workers spend their wage income on consumption goods and rental accommodation, i.e., $w=y_{L}+q h_{L}$ where $q$ is the market price of rented accommodation. Individual demand for housing is $h_{L}=q^{\frac{-1}{1-\beta}}$. If rented accommodation is taxed, the capitalist, who owns the property, pays it on behalf of the worker(s) occupying the property. In general, the incidence of the tax depends on the relative elasticities of demand and

\footnotetext{
${ }^{29}$ This requires that $n_{L}>\frac{\alpha}{1-\alpha} \frac{n_{M} k_{M}+n_{H}}{k_{M}} k_{H}$. This condition also insures that capitalists do not want to become workers.
} 
supply. In the short run, the supply of rented accommodation is fixed and the full incidence falls on the capitalists. In the long run, the stock of housing is variable and the incidence can be shifted onto workers. As we discuss in detail in Section 4.5, it is not important for the results how the incidence is divided. For simplicity, we focus on the short run and keep the supply of rented accommodation fixed. In this case, the rental income of each capitalist is $r^{*}=q^{*}-\tau_{L}$ where $q^{*}=n_{L}^{1-\beta}\left(n_{H}+n_{M}\right)^{\beta-1}$ is the market clearing price and, if applicable, $\tau_{L}$ is the tax levied on each unit of rented accommodation. ${ }^{30,31}$ Capitalists spend profits and income from letting net of taxes on the consumption good.

Combining the analysis above, the following policy preference functions emerge:

$$
\begin{aligned}
v_{i}(g) & =B+\pi_{i}^{*}(g)-I_{i} \tau_{i}-I_{L} \tau_{L} \quad i \in\{H, M\} \\
v_{L}(g) & =C+w^{*}(g),
\end{aligned}
$$

where $B=\beta^{-1}+q^{*}$ and $C=\frac{(1-\beta)}{\beta}\left(q^{*}\right)^{\frac{-\beta}{1-\beta}}$ are independent of fiscal policy. $I_{i}$ is an indicator variable equal to 1 if and only if the properties occupied by capitalists of type $i$ are taxed. $I_{L}$ is equal to 1 if rented accommodation is taxed and 0 otherwise. Workers want spending on public goods to be high, as they benefit from higher wages and effectively to do not bear the tax cost. Tax-paying capitalists, on the other hand, face a trade-off between the higher profit earned in a more productive urban economy and the cost of paying the necessary taxes.

\subsection{Politics}

The property taxes were regressive. We capture this in the model by assuming that they are uniformly levied on all rated property and not in proportion to the income of the occupier. ${ }^{32}$ Provision of local public goods and the corresponding uniform property tax, $\tau$, is determined by representative democracy. We assume that citizen candidates can

\footnotetext{
${ }^{30}$ If $\tau_{L}$ is sufficiently large, $r^{*}$ could be negative. If so, capitalists must pay (part of) the tax out of profit income.

${ }^{31}$ To insure that workers can afford consumption goods, we assume that $w^{*}>q^{*} h_{L}^{*}=\left(\frac{n_{L}}{n_{H}+n_{M}}\right)^{\beta}$.

${ }^{32}$ In practice, a higher tax was sometimes levied on property of higher value, but this was never sufficient to make the local property taxes progressive relative to the income of the occupier. To keep things simple, we ignore this detail.
} 
stand for election to the council only at a cost (Besley and Coate, 1997; Osborne and Slivinski, 1996). ${ }^{33}$ Payment of local property taxes is a necessary condition for being allowed to vote and to stand for election; conversely, only enfranchised citizens can be taxed. We assume that enfranchised citizens vote sincerely and support the candidate whose platform maximizes their utility. ${ }^{34}$ The timing of events is:

1. Any enfranchised citizen can decide to stand for election at a group-specific cost $\epsilon_{i} \in\left\{\epsilon_{H}, \epsilon_{M}, \epsilon_{L}\right\}$.

2. An election is held amongst candidates. The candidate getting the most votes wins. ${ }^{35}$

3. The winning candidate controls the council. He implements his most preferred policy $\{g, \tau\}$ subject to the council's budget constraint. If nobody runs, the default policy $g_{0}=0$ is implemented. ${ }^{36}$

In this game, the players are the citizens with the action space "to enter" or "not to enter". We study subgame perfect equilibria. To simplify the analysis, we assume:

Assumption $1 \varepsilon_{H} \rightarrow 0^{+}$and $\varepsilon_{M} \rightarrow 0^{+}$

Assumption $2 \varepsilon_{L} \rightarrow \infty$

Assumption 1 combined with $A\left(g_{0}\right)=0$ guarantees that at least one candidate is willing to stand for election. More importantly, it also guarantees that a candidate favoured only by a minority of the enfranchised voters cannot gain office in an uncontested election

\footnotetext{
${ }^{33}$ The citizen candidate model is a natural modelling choice in the context of mid-victorian Britain. It explicitly acknowledges i) that politicians typically ran as individuals rather than as members of political parties, ii) that the cost of running played an important role in keeping certain groups out of the councils, and iii) that politicians in the absence of strong party discipline would find it difficult to commit to preelection promises. The two obvious modelling alternatives, the probabilistic voting model or the median voter model, do not deal well with these points. The probabilistic voting model assumes stable twoparty politics and that parties can commit to policy platforms. The median voter model is often seen as institution free. However, it does require that citizens can freely propose platforms and it is ill-suited to an institutional setting of representative democracy.

${ }^{34}$ This is similar to Osborne and Slivinski (1996).

${ }^{35}$ In case of a tie, an unbiased lottery is held amongst the candidates.

${ }^{36}$ The default policy implies the income of all citizens is zero and that the rental market closes down. This assumption can be relaxed.
} 
because potential candidates from the opposition find it too expensive to run. Assumption 2 implies that workers never run, as it was the case in practise. ${ }^{37}$

\subsection{Three Franchise Regimes}

We begin by studying policy outcomes under three (exogenously) given franchise regimes: $H$-franchise, $H M$-franchise and $H M L$-franchise. Under $H$-franchise only the wealthy capitalists - the urban elite - can vote, stand for election and have their property taxed. Under $H M$-franchise all capitalists can vote, stand for election and have their property taxed. Under $H M L$-franchise all citizens can vote and stand for election, and all property, including rented accommodation, can be taxed. The policy outcomes under the three regimes can be summarized as follows (see Appendix for details).

Under $H$-franchise, the wealthy capitalists control the council and decide on spending and taxation bearing in mind that they cannot share the cost of public goods with the other groups. Spending on local public goods is $g_{H}$ satisfying

$$
A^{\prime}\left(g_{H}\right) k_{H} x=\frac{1}{n_{H}},
$$

and the property tax is $\tau_{H}=\frac{g_{H}}{n_{H}}$. An extension of the franchise to $H M$-franchise brings the middle class into power, as it outnumbers the elite. The middle class benefits less from spending on local public goods than the urban elite, but can take advantage of the broader tax base $\left(n_{H}+n_{M}\right)$. Spending on local public goods is $g_{M}$ satisfying

$$
A^{\prime}\left(g_{M}\right) k_{M} x=\frac{1}{n_{H}+n_{M}}
$$

and the property tax is $\tau_{M}=\frac{g_{M}}{n_{H}+n_{M}}$. Enfranchisement of workers creates a cross-class alliance between workers and wealthy capitalists. Since it is too costly for workers to stand for election themselves, they vote for a wealthy capitalist, who can be trusted to spend more than a middle class capitalist. ${ }^{38}$ This brings the urban elite back into power and

\footnotetext{
${ }^{37}$ Both of these assumptions can be relaxed. The results reported below hold provided $\varepsilon_{H}$ and $\varepsilon_{M}$ are "small" and $\varepsilon_{L}$ is "large". If not, there exists equilibria in which a minority candidate get elected and/or equilibria in which a working class candidate stands and gets elected. These equilibria cannot exhibit retrenchment effects.

${ }^{38}$ Compared to the Samuelson solution, local public goods are underprovided by a taxpayer democracy under $H$ - and $H M$-franchise and continues to be underprovided under $H M L$-franchise if $n_{M}\left(k_{H}-k_{M}\right)<$ $\frac{\alpha}{1-\alpha}\left(n_{M} k_{M}+n_{H} k_{H}\right)$.
} 
spending on local public goods is $g_{L}$ satisfying

$$
A^{\prime}\left(g_{L}\right) k_{H} x=\frac{1}{n_{H}+n_{M}}
$$

and the property tax is $\tau_{L}=\frac{g_{L}}{2\left(n_{H}+n_{M}\right)}$. The first proposition compares spending levels under the three franchise regimes.

Proposition 1 (The Retrenchment Hypothesis) Spending on local public goods is higher under $H$-franchise than under $H M$-franchise if and only if

$$
\frac{k_{H}}{k_{M}}>\frac{n_{M}+n_{H}}{n_{H}} .
$$

Spending on local public goods is always higher under HML-franchise than under $H$ - or $H M$-franchise.

Proof. Since $A(g)$ is strictly increasing and concave, equations (5) and (6) imply that $g_{H}>$ $g_{M}$ if and only if $\frac{k_{H}}{k_{M}}>\frac{n_{M}+n_{H}}{n_{H}}$. Moreover, $g_{L}>\max \left\{g_{H}, g_{M}\right\}$ because $\left(n_{M}+n_{H}\right) k_{H}>$ $\max \left\{\left(n_{M}+n_{H}\right) k_{M}, n_{H} k_{H}\right\}$

Whether enfranchisement of the middle class leads to retrenchment or not depends on a trade-off between two effects. On the one hand, under $H M$-franchise, the cost of spending on local public goods can be spread over more taxpayers than under $H$-franchise. This tax base effect pulls in the direction of more spending. On the other hand, under $H M$ franchise the power of the council falls into the hands of the middle class. It benefits less from spending on public goods than the elite. This benefit effect pulls in the direction of lower spending. Condition (8) guarantees that the benefit effect dominates. It requires large wealth inequalities (large benefit effect) and/or a relatively small middle class (small tax base effect). An extension of the franchise to the working class, in contrast, is always associated with an increase in spending. This is because the elite returns to power with the votes of the workers.

\subsection{Extension of the Franchise}

Above we took the franchise regime as given, leaving aside the determinants of the extension of the franchise. As discussed in Section 2.1, the boundaries of the franchise were 
in practice determined by two broad factors. Firstly, by not taxing certain properties, by disenfranchising indirect taxpayers or occupiers of shared accommodation etc., the boundaries could be manipulated locally. Secondly, nation-wide legislation could force an extension through. Theoretically, we make a distinction between a voluntary extension of the franchise that is "agreed" locally and a "forced" extension that is driven by nation-wide legislation.

Initially, the franchise of the city only allows wealthy capitalists to vote $-H$-franchise - but subsequently, the middle class and possibly also the working class might become enfranchised. We say that a franchise extension is voluntary if all citizens are better off under the new franchise regime than under the old, i.e., the new franchise regime is Pareto superior. $^{39}$ Voluntary enfranchisement is likely to happen endogenously. ${ }^{40}$

Proposition 2 (Voluntary enfranchisement of the middle class) HM-franchise is Pareto superior to $H$-franchise if and only if

$$
\left(A\left(g_{M}\right)-A\left(g_{H}\right)\right) k_{M} x>\tau_{M}
$$

A voluntary extension of the franchise to the middle class is always associated with an increase in spending on local public goods. Moreover, once HM-franchise has been granted, enfranchisement of the working class cannot be voluntary.

\section{Proof. See Appendix}

A voluntary extension of the franchise to the middle class is possible because representation is linked to taxation. The elite loses power by granting the middle class the right to vote, but the tax base is broadened, reducing the cost of local public goods. An enfranchised middle class gains political influence, but this comes with the price tag of

\footnotetext{
${ }^{39}$ This is a strict definition of voluntary enfranchisement. It requires consent even from citizens who are only indirectly affected by the extension. The results are, however, identical if we only require that those who give the vote away and those who receive it (but not other citizens) are better off.

${ }^{40}$ When there is disagreement locally about where the boundaries of the franchise should be drawn, those in favor of an extension may be able to force it through. However, in this case the losers are likely to response by evading tax payments. If so, it becomes doubtful if they would be granted the franchise in the first place. Such taxpayer revolts are less likely to happen if all parties "agree" to the extension (and to the associated obligation to pay taxes). For this reason, we associate endogenous enfranchisement with consensus.
} 
having to share the tax cost. Proposition 2 shows that a voluntary extension is feasible if and only if the middle class is willing to accept the franchise. A voluntary extension of the franchise to the middle class must be associated with an increase in spending on local public goods. Intuitively, if the middle class wants less public goods than the elite, it does not want to pay for the reduction. An important implication, then, is that middle class taxpayer retrenchment cannot be the result of a fully voluntary (endogenous) extension of the franchise. It must be associated with forced enfranchisement. Moreover, once the middle class has been enfranchised, enfranchisement of the working class cannot be voluntary because the middle class would lose political power without any compensating benefits and thus be against further democratization.

We say that enfranchisement is forced if all citizens are worse off under the new franchise regime than under the old, i.e., the new franchise regime is Pareto inferior.

Proposition 3 (Forced enfranchisement of the middle class) HM-franchise is Pareto inferior to $H$-franchise if and only if

$$
\left(A\left(g_{H}\right)-A\left(g_{M}\right)\right) k_{H} x>\tau_{H}-\tau_{M}
$$

A forced extension of the franchise to the middle class is always associated with a reduction in spending on local public goods.

\section{Proof. See Appendix}

The proposition demonstrates that democratization may be wholly unwanted. The elite is obviously reluctant to give up control of the council. Less obvious, perhaps, is the fact that the middle class may not want to accept democratic rights. They sometimes prefer to forego political influence in order to avoid paying taxes. Proposition 3 shows that whenever the elite is unwilling to give away the vote, the middle class would not want to accept it anyway. Thus, the condition for forced enfranchisement of the middle class is that the elite values the right to decide on spending more than a broader tax base. Importantly, a forced extension of the franchise to the middle class is always associated with a reduction in spending on local public goods; thus making even workers worse off. Moreover, if the 
extension from $H M$-franchise is forced, a further (partially forced) extension to $H M L$ franchise will always lead to an increase in spending (see Proposition 1). ${ }^{41}$ Thus, forced enfranchisement is consistent with the retrenchment hypothesis.

We can gain more insight into the conditions for voluntary and forced franchise extensions by assuming that $A(g)=\frac{1}{\gamma} g^{\gamma}$ with $\gamma \in(0,1)$. With this assumption, we can rewrite conditions (9) and (10) as follows

$$
\frac{n_{M}+n_{H}}{n_{H}}>\frac{k_{H}}{k_{M}}(1-\gamma)^{\frac{\gamma-1}{\gamma}}
$$

and

$$
\frac{n_{M}+n_{H}}{n_{H}}<\frac{k_{H}}{k_{M}}\left(\frac{1-\gamma}{1-\gamma \frac{k_{M}}{k_{H}}}\right)^{\frac{1-\gamma}{\gamma}} .
$$

A voluntary extension of the franchise is more likely in cities with a large middle class to shoulder the tax burden and with little wealth inequality. In contrast, a forced extension is required to enfranchise the middle class in cities with a small middle class and high wealth inequality.

Taking together these propositions provide an explanation of the uneven extension of the franchise observed across mid-Victorian boroughs. The citizens of boroughs with a relatively large middle class and modest wealth inequalities faced a strong incentive to enfranchise the middle class and maybe even the working class voluntary: ${ }^{42}$ all citizens would benefit. In contrast, the citizens of boroughs with a relatively small middle class and large wealth inequalities all stood to lose from enfranchisement of the middle class. In those boroughs, the franchise was unlikely to be extended beyond the urban elite in the absence of nation-wide reforms. Importantly, local decisions to extend or restrict the franchise are based on a comparison of the size of the tax base before and after and on relative wealth levels. In contrast, spending decisions for a give franchise is determined solely by the size of the current tax base and the wealth level of the ruling majority. The model also shows that the source of middle class retrenchment is forced enfranchisement.

\footnotetext{
${ }^{41}$ The extensions from $H M$-franchise to $H M L$-franchise cannot be fully forced as workers welcome the increase in spending.

${ }^{42}$ It can be shown that enfranchisement of the middle and working class is a Pareto improvement if the middle class is relatively large and wealth inequality is low. A proof is available upon request.
} 
Only if the franchise is forced upon the middle class, their preference for economy leads to a reduction in the supply of local public goods. Voluntary extension of the franchise to the middle class is associated with higher spending, not lower. We shall draw upon these observations when we develop our empirical test of the retrenchment hypothesis below.

\subsection{The incidence of the Property Tax}

The assumption that the supply of housing is fixed may appear to be too restrictive and unrealistic. Clearly, in the long run, the supply of rented accommodation reacts to market forces. As it becomes more elastic, the incidence of the local property tax is shifted onto workers. Fortunately, the incidence of the tax and thus the distinction between the short and long run is unimportant for the qualitative nature of the main results.

To see this, suppose that the full incidence of any tax levied on rented accommodation falls on workers. ${ }^{43}$ Under $H M L$-franchise workers now want less spending on local public goods than the capitalists because they benefit less at the margin $\left(z<k_{M} x\right)$. As a consequence, they prefer a candidate from the middle class rather than one from the elite, and a middle class candidate runs and gets elected. Importantly, however, spending is still higher under $H M L$-franchise than under $H M$-franchise. This is because the successful middle class candidate takes advantage of the enlarged tax base. Thus, although the reason for the increase in spending associated with $H M L$-franchise is different, condition (8) continues to determine if the retrenchment hypothesis holds or not, irrespective of the incidence of the tax levied on rented accommodation.

With respect to voluntary enfranchisement, the only new feature is that the extension from $H M$ - to $H M L$-franchise can be voluntary in the long run. The middle class is obviously in favor of such an extension: it keeps power and gains control over a larger tax base. The elite may appreciate the larger tax base sufficiently to also support the extension. Surprisingly, even workers might agree to pay taxes in exchange for the vote despite the fact that they cannot gain control of the borough council. ${ }^{44}$ The long run

\footnotetext{
${ }^{43} \mathrm{An}$ appendix with the details is available upon request.

${ }^{44}$ This requires that the successful middle class candidate chooses a spending level that is sufficiently close to the policy that workers would have chosen if they could have decided themselves and that the spending level under $H M$-franchise is much lower than this.
} 
versions of Propositions 2 and 3, then, in addition to conditions (9) and (10), require a new condition that rules out that the franchise is voluntarily extended from $H M$ - to $H M L$-franchise, once $H M$-franchise is granted.

\section{Estimation Strategy and Data}

We have constructed an unbalanced panel data set with three cross sections $(1868,1871$, and 1886) for the 75 Corporations that had taken control of the Local Board of Health by 1868. In addition to information on spending on urban amenities and borrowed funds and the extension of the voting franchise, it contains information from the Population Census and other sources on socioeconomic conditions. ${ }^{45}$ As with all historical data, the accuracy can be questioned. We, however, have no reasons to believe that the (in)accuracy of the fiscal data is systematically related to the measure of the extension of franchise. While measurement error in the fiscal data, then, inflates the error variance and may be a source of heteroskedasticity, we do not suspect this to be an important source of bias. Measurement error in the registered number of voters is less likely to be a problem. This is because the borough officials would have these numbers on record and just needed to do a count to provide a return. The Appendix contains a detailed discussion of data and sources.

It is useful to start by eyeballing the data. Table 3 shows the number of voters as percentage of the adult male population, income from property taxes, and spending on urban amenities in 1871 for 21 boroughs. We have selected the boroughs to match as closely as possible those included in Williamson's (1990) seminal study on city growth during the industrial revolution. The boroughs are ranked according to the extension of the franchise and divided into three equal-sized groups. The retrenchment effect is clearly visible in the raw data: boroughs with a narrow or a broad franchise tended on average to spend less on urban amenities than those in the middle. Similar pictures emerge in 1868 and 1886.

<Table 3: The franchise and spending on urban amenities in 21 boroughs, 1871.>

\footnotetext{
${ }^{45}$ Missing information on some of these variables reduces the sample to between 55 and 69 boroughs.
} 


\subsection{Panel Regressions and Results}

We begin the econometric analysis by presenting panel regressions of the following type:

$$
g_{i t}=\alpha_{1} f_{i t}+\alpha_{2} f_{i t}^{2}+X_{i t} \beta+\alpha_{i}+\mu_{t}+\varepsilon_{i t},
$$

where $g_{i t}$ is investment in urban amenities per capita in borough $i$ at time $t$, either measured as spending on urban amenities or as borrowed funds; $f_{i t}$ is the number of registered voters in percentage of the adult male population; $X_{i t}$ is a vector of control variables and $\varepsilon_{i t}$ captures all unobserved factors. We assume $E\left(\varepsilon_{i t}\right)=0$. The retrenchment hypothesis postulates a U-shaped relationship between spending on urban amenities and the extension of the franchise, or more precisely that $\alpha_{1}<0$ and $\alpha_{2}>0$.

The choice of the five time-varying included in $X_{i t}$ is motivated by the theoretical model. The size of the tax base plays an important role in the theory. The Population Census provides information on the number of individuals working in different occupations. We have experimented with different occupation shares and settled on the share of employment in manufacturing (industrial employment) as the best measure of the size of the tax base. As an alternative measure we use the average rateable value of properties within the borough (ratable value). The number of inhabitants per house (population density) is included to capture differences in population density. This is likely to affect the cost of provision, but also the demand for services. We include the size of the total population (population) to capture scale effects. Finally, we include the stock of outstanding debt (accumulated debt). Since borrowed funds had to be invested in capital projects, the stock of debt is a reasonable indicator of past spending on urban amenities. It is clearly important to control for this as the need to spend on urban amenities in the present depends on how much was spent in the past. Past spending, of course, also increases the cost of maintenance. ${ }^{46}$

In addition to these time-varying, observable factors, we control for borough and time fixed effects. These capture unobserved factors within a borough that are constant over time and common shocks that affect all boroughs in a given year, respectively. Under the

\footnotetext{
${ }^{46}$ It is not possible to construct a measure of the stock of urban amenities from past investment flows. This is because the Local Taxation Returns do not extend back further than 1868 .
} 
assumption that $f_{i t}$ is uncorrelated with $\varepsilon_{i t}$, conditional on observables and fixed effects, we can obtain consistent estimates of $\alpha_{1}$ and $\alpha_{2}$ by applying a fixed effects estimator to equation (13). However, regressions with fixed effects do not necessarily estimate a causal effect. One potential problem is omitted time-varying factors that affect spending on urban amenities in borough-specific ways. Insofar as these factors are correlated with the extension of the franchise, the fixed effects estimator is inconsistent. We deal with this concern by including shire-specific time trends in the model.

Regressions (1) to (3) in Table 4 (spending on urban amenities) and regressions (6) to (8) in Table 5 (borrowed funds) contain the main results. These regressions include borough fixed effects, borough and time fixed effects, and borough and time fixed effects and shire-specific trends, respectively. ${ }^{47}$ In all cases, the estimates of $\alpha_{1}$ and $\alpha_{2}$ are consistent with the retrenchment hypothesis and are significant, at least, at the 10 per cent level. ${ }^{48}$ Despite some differences in the magnitude of the point estimates, the estimated turning point $\left(\frac{-\alpha_{1}}{2 \alpha_{2}}\right)$ at around 40 per cent is remarkable stable across specifications. This implies that democratization would have led to a reduction in spending on urban amenities in boroughs with less than 40 per cent of the adult male population on the electoral roll, and to an expansion in boroughs with a wider franchise than that. Based on time averages, about 40 per cent of the boroughs are located below this turning point.

[Tables 4 and 5 to appear here.]

For comparison, in regressions (4) and (9), we report the results from estimations with pooled OLS. ${ }^{49}$ These results are also consistent with the retrenchment hypothesis with a turning point similar to that of the fixed effects estimations. More importantly, in regressions (5) and (10), we reestimate the model on the pooled sample using median regression techniques. This reduces the impact of outliers that might arise if expenses (or funds borrowed) for large improvement projects were recorded in a particular year rather

\footnotetext{
${ }^{47}$ The estimated standard errors are robust to arbitrary heteroskedasticity.

${ }^{48}$ We have tried to include higher order polynomial terms (including a cubic term). These terms are always insignificant.

${ }^{49}$ We allow for panel heteroscedasticity and for spatial correlations between the error terms across boroughs, and the reported standard errors of the parameter estimates are panels corrected standard errors (PCSEs), as recommended by Beck and Katz (1995).
} 
than spread over time. We see that it makes little difference. This reduces the concern that the results are due to outliers.

The time-varying controls are, with the exception of accumulated debt and industrial employment, only significant in the pooled OLS regressions and even there, not in all cases. This is not surprising, as borough fixed effects reduce the variation from which the impact of these variables are estimated to deviations from borough averages. In contrast, it is surprising to note that the time fixed effects are often insignificant. This suggests that the boroughs were exposed to few common fiscal shocks. We shall return to this point in Section 5.2. The shire-specific trends are, on the other hand, highly significant.

We have preformed many robustness checks. ${ }^{50}$ Firstly, we have added additional control variables, including measures of other sources of income than local property taxes, the growth rate of the housing stock over the previous 10 years, and borough-specific trends. Secondly, we have introduced fiscal lags of 5 years. Thirdly, we have balanced the panel. Fourthly, we have eliminated variables according to a general-to-specific procedure. Fifthly, we have clustered the standard errors within boroughs and allowed for arbitrary serial correlation. Finally, we have also estimated the model with random rather than fixed effects and with a Tobit estimator to deal with potential corner solution problems that arise when some boroughs did not spend anything on urban amenities. The basic results presented above are robust to all these extensions.

\subsection{Instrumental Variable Estimates}

The panel regressions reported in the previous section only loosely draw on the theoretical model. In this section, we utilize the theory more systematically to derive restrictions that can help identify the retrenchment effect. The theory suggests that:

1. The retrenchment effect is associated with forced enfranchisement.

2. The endogenous decision to extend the franchise depends on how far the franchise has already been extended.

\footnotetext{
${ }^{50}$ Tables with all these results are included in the supplementary material at the back of the paper.
} 
3. The fiscal choice under a given franchise is determined by the absolute size of the tax base and by the absolute wealth level of the ruling majority.

4. The endogenous decision to extend the franchise is determined by the relative size of the tax base and by relative wealth levels.

These observations point to variables that can be used as instruments for the franchise in the spending equation. ${ }^{51}$ First, all boroughs were exposed to three nation-wide reforms with implications for the franchise: the Municipal Franchise Act of 1869, the Assessed Rates Act of 1869, and the Municipal Corporation Act of 1882. These reforms were introduced precisely in between the three cross sections. The factors behind these reforms are unlikely to be associated with the politics or fiscal situation of any particular borough. Accordingly, these reforms constitute natural experiments and sources of exogenous variation, and based on observation 1 we can use reform dummy variables as instruments.

Second, observation 2 suggests that lags of the franchise can be used as a instruments. To be valid, however, the lagged value of the franchise (and its transformations) must be uncorrelated with (the unobserved component of) spending on urban amenities in the present. This is a concern because the franchise of the past affects past spending levels which may, in turn, affect present spending levels. To deal with this, we condition on past spending levels (accumulated debt) in the equation for current spending. We also use long lags, namely the franchise in 1852, 1865 and 1871 as instruments for the franchise in 1868, 1871 and 1886, respectively. ${ }^{52}$ All this makes it plausible that the franchise of the distant past only affects current spending through its influence on the current franchise.

Third, observations 3 and 4 suggest that measures of the relative size of the tax base and of relative wealth levels can be used as instruments for the franchise. The number of individuals listed as being engaged in commercial activities in the Population Census in percentage of the number of individuals either listed as being engaged in commercial

\footnotetext{
${ }^{51}$ These instruments would also take care of (classical) measurement errors.

${ }^{52}$ We have tested for serial correlation in the error term of the equation that determines the franchise. This is difficult to do because the estimated time-demeaned errors are negatively correlated if the true errors are uncorrelated. An application of the test suggested by Wooldridge (2002, chapter 10), allowing the current franchise to be a linear or quadratic function of the past franchise, strongly indicates that serial correlation is not a problem.
} 
activities or listed as professionals (relative tax base) gives a good indication of the relative size of the tax base. Finding a reasonable measure of the wealth distribution is more difficult. However, we can use information on the sums of money raised through income taxation. The British income tax was levied by the central government from 1842 onwards. It was based on the source principle and divided income into five different schedules (see Daunton, 2001, p. 185). In particular, schedule D was a tax on profits from trade, commerce and professions. The percentage of total income tax revenues raised under schedule D (relative wealth) gives an indication of the share of income earned by the middle class. Unfortunately, this information is only available at the county level. We must therefore attribute the county average to each borough within the county.

Given this set of instruments, we estimate the panel model using fixed effects 2SLS. ${ }^{53}$ To economize on the degrees of freedom, we progressively excluded insignificant timevarying control variables using a general-to-specific approach. ${ }^{54}$ Table 6 reports the results for the two specifications with spending on urban amenities and borrowed funds. ${ }^{55}$ The instruments pass Hansen's J test for over-identifying restrictions. All instruments, except relative wealth, are highly significant in the two first stage regressions with high partial $\mathrm{R}^{2}$ values and a large F-statistics for joint significance. Most importantly, the estimations continue to support the retrenchment hypothesis. The estimated turning point is, in line with the previous results, somewhere in the range between 33 and 44 per cent.

[Tables 6: Results from IV estimation.].

The nation-wide reforms that play an important role in our IV estimations are indistinguishable from time fixed effects. These must therefore be excluded from the second stage regressions. As noted in Section 5.1, however, the fixed time effects are mostly insignificant, and we feel justified in excluding them. To check the robustness of this, regressions (16) to (18) include regional-specific time trends. This makes very little difference to the

\footnotetext{
${ }^{53}$ The use of these instruments reduces the sample size to 77 observation from 35 boroughs.

${ }^{54}$ Similar results obtain if we leave all insignificant control variables in the first and second stage regressions (not reported).

${ }^{55}$ Since we include the same variables in all regressions, the first stage regressions are only reported once in Table 6.
} 
results.

\section{Conclusion}

We have shown that local democracy can be a source of retrenchment. In our context, it is reasonable to suppose that retrenchment and the associated reduction in spending on urban amenities was socially harmful. In other contexts, it is possible that retrenchment can be socially desirable, for example by taming a Leviathan government.

From a broader perspective, our analysis shows that franchise extension needs not be associated with larger government, as otherwise suggested by the theory developed by Meltzer and Richards (1981) and others. In particular, the tax policy used to finance public spending plays an important role. While Lindahl (1964) argued that a tax system linked to marginal benefits can foster consensus, our evidence suggests that retrenchment emerges out of social conflict when taxes are broadly unrelated to the benefits of spending but closely linked to political rights.

Recent empirical work on the consequences of the extension of the franchise have focused on fiscal and other outcomes at the national level or at the state level in the USA. While the evidence from US states presented by Husted and Kenny (1997) and Kenny and Lott (1999) broadly supports the view that national franchise reforms contributed to the growth of government, the evidence from Western Europe is more complex. Aidt et al. (2006) find that the franchise extension had more of an impact on the composition of spending than on the scale of government. Aidt and Jensen (in Press) show that the impact of the franchise extension on the composition of taxes depended critically on tax collection technology, and that the franchise was not associated with growth in direct taxation until tax collection technologies had reached a certain threshold. A similar point is made by Aidt and Jensen (2007) who show that the probability of adopting income taxation in Western Europe was, in fact, negatively related to the extension of the franchise. ${ }^{56}$ For a broader sample of countries, Mulligan et al. (2002) find little evidence of a linear

\footnotetext{
${ }^{56}$ See also Lindert $(1994,2004 a, b)$ for evidence on the link between democratization and social spending, and Engerman and Sokoloff (2005) for a study of the franchise extension in the Americas.
} 
relationship between democracy and social security policy and stress that countries with very different political histories often end up with very similar social security programmes. Taken together with our finding of retrenchment, this evidence cast doubt on the simply hypothesis that democratization must be associated with growth government.

The fact that the mid-Victorian Municipal Corporations had considerable fiscal independence combined with the large inter-borough variation in the extension of the franchise offer new opportunities to investigate the interaction between fiscal choices and the allocation of voting rights. We have focused on one aspect - the retrenchment hypothesis but the data material can be used to test many other in future research.

\section{Data Appendix}

The data set has been deposited with the UK Data Achieve (http://hds.essex.ac.uk).

Construction of the data set. The unit of analysis is a Municipal Corporation in a particular year. The data set covers up to 75 Corporations. The fiscal data refers to the fiscal years ending in 1868, 1871, 1875, 1886 and 1888. The data comes from the annual reports (the Local Taxation Returns) submitted by each Corporation, Local Board or Urban Sanitary Authority to Parliament detailing the expenditures and incomes of the past fiscal year. We aggregate the accounts of the Corporations with those of the Local Board for the years 1868 and 1871. For 1874, 1885, 1888, the accounts for the Urban Sanitary Authority replace those of the Local Board. The Corporations are selected to maximize sample size subject to the constraint that the relevant Corporation acted as the Local Board in 1868 (accordingly British Parliamentary Papers, LVI, 1874) and to data availability. All data is in current prices and refers to a fiscal year of 12 months. Prices were generally falling during the period. Contemporaneous information on borough-specific prices is not available. Information on income tax revenues by county comes from special returns reported in British Parliamentary Papers.

Information on the franchise for the Corporations has been collected for 33 boroughs in 1852, 63 boroughs in 1865, 73 boroughs in 1871, and 75 boroughs in 1884. The data for 1865 is matched with fiscal data for 1868, the data for 1871 is matched with fiscal data for 1871, and the data for 1884 is matched with fiscal data from 1886.

The socioeconomic controls are only available from the Censuses by decade. We have interpolated linearly to match the information to the relevant year. Population data by age is only available from the Censuses at the municipal borough level for a subset of the cities for 1861 and 1871. For the some boroughs, the age-specific data are taken from the relevant registrar's sub-district and has been scaled to match the borough totals (as they appear in British Parliamentary Paper (1871) LIX vol 3 and 4, p. 701-707). A similar 
problem arises when the age-specific data refer to parliamentary boundaries. Data on employment structure is only available for 30 boroughs in the 1881 Census.

\section{Definitions of variables used in the regression analysis}

- Spending on urban amenities is the sum of Public Works and Maintenance and Repairs from the Corporation's accounts and Public and Private Improvements Works from the accounts of the Local Board or the Urban Sanitary Authority. This includes spending on sewage, water supply, gas supply, highway scavenging and watering and drainage.

- Borrowed funds is the sum of Money Borrowed on Security of the Rates from the Corporation's accounts and Loans on Security of Rates from the accounts of the Local Board or the Urban Sanitary Authority.

- Franchise is the total number of individuals on the Burgess Roll divided by the number of male inhabitants in the municipal borough, aged above 20, times 100.

- Population is the total population in the municipal borough (borough boundaries).

- Population density is the total population divided by the number of inhabited houses in the municipal borough times 100.

- Industrial employment is the number of male and female workers in the industrial class (V) in registration districts divided by the number of adult (older than 20 years) males and females in the registration district, times 100.

- Ratable value is the value of all rated property in the parish or district divided by the number of properties in the parish or district times 100.

- Accumulated debt is the stock of debt outstanding at the end of the fiscal year, as stated in the Corporation's accounts and in those of the Local Board or the Urban Sanitary Authority.

- Relative tax base is the number of individuals listed as being engaged in commercial activities in the Population Census in percentage of the number of individuals listed as either being engaged in commercial activities or are listed as professionals.

- Relative wealth is the percentage of total income tax revenues raised under schedule D.

- Housing stock is the number of inhabited houses in the municipal borough (borough boundaries). 
- Rents and profits is the sum of Tolls and Dues, Duties, Penalties, Fines and Fees, and Rents and Profits of Property from the Corporation's accounts and Profits from Water and Gas Works and Income from Markets, Rents, Tolls and Dues from the accounts of the Local Board or the Urban Sanitary Authority.

[Table A1: Descriptive statistics.]

Sources The data comes from House of Commons British Parliamentary Papers (PP henceforth). The sources for the fiscal data are:

- PP (1868-69) "Abstract of the statement of the municipal boroughs in England and Wales for the year ended 31 August 1868," LII, 149-167.

- PP (1868-69) "Return of the Rates Levied by Local Boards," LII, 377-397.

- PP (1872) "Abstract of municipal borough accounts: Monies raised and expended by the municipal boroughs of England and Wales, year ended 31 August 1871," XLIX, 149-167.

- PP (1873) "Sums Raised and Expended by Local Boards for the year 1871-72," Local Board Rates, No. 3.

- PP (1876) "Abstract of the Municipal Borough Accounts, year ended 31 August 1875" Municipal Borough Rates (England).

- PP (1872-73) "Sums Raised and Expended by Urban Sanitary Authorities for the Year 1872-73," Urban Sanitary Authorities, No. 2.

- PP (1868-69), "Abstract of the statement of the municipal boroughs in England and Wales for the year ended 31 August 1868," LII, 149-167;

- PP (1886) "Sums Received and Expended by Town Councils Acting as Urban Sanitary Authorities, Year ended Lady-day 1886," Borough Urban Sanitary Accounts, No. 5.

- PP (1886) "Abstract of the Municipal Borough Accounts, year ended Lady-day 1886," Municipal Borough Accounts, No. 4.

- PP (1888) "Abstract of the Municipal Borough Accounts, Year ended Lady-day 1888," Municipal Borough Accounts, No. 4.

- PP (1888) "Sums Received and Expended by Town Councils Acting as Urban Sanitary Authorities, Year ended Lady-day 1888," Borough Urban Sanitary Accounts, No. 5. 
- PP (1870) "Return of the amounts of property asses to income and property tax under Schedules A, B and D in each country in England and Wales and Scotland, in each of the years from 1864-5 to 1869-70".

- PP (1885) "Return of the income tax under schedule A, B, D, of gross amount of property and profits assessed in each county of Great Britain in the years 1883-54".

The sources for the franchise data are:

- PP, 1867, LVI (355-433): "Return of the number of registered voters on the list of all municipal boroughs in England and Wales and of the numbers who voted at the municipal elections in those boroughs for the year 1852 and all subsequent years."

- PP, 1872, XLVII: "Return showing with respect to each Municipal City and Borough in England and Wales, the total number of municipal electors on the register now in force."

- PP, 1884-84. LXVII (23-31): "Return of municipal boroughs in England and Wales, showing the population, number of inhabited houses, number of persons on the Burgess rolls, distinguishing men from women."

The sources for the demographic and occupational data are the 1851, 1861, 1871, 1881 and 1891 Censuses and PP (1871) LIX vol 3 and 4, (701-707): "Houses and populations in the cities and boroughs in England, table VIII: houses and populations in the cities and boroughs having defined Municipal or Parliamentary limits."

\section{Proofs}

Characterization of policy outcomes. First, consider $H$-franchise. Suppose a wealthy capitalist stands for election and is elected. He implements $g_{H}=\arg \max \pi_{H}^{*}(g)-\tau$ subject to $g=\tau n_{H}$ where $g_{H}$ satisfies $A^{\prime}\left(g_{H}\right) k_{H} x=\frac{1}{n_{H}}$. If no one stands for election, the default policy is $g_{0}=0$ which yields $v_{H}(0)=\beta^{-1}$. At least one wealthy capitalist will run if

$$
v_{H}\left(g_{H}\right)-\varepsilon_{H} \geq \beta^{-1}
$$

which is always satisfied for $\varepsilon_{H} \rightarrow 0^{+}$.

Second, consider $H M$-franchise. Suppose a capitalist of type $i$ is elected. He implements $g_{i}^{H M}=\arg \max \pi_{i}^{*}(g)-\tau$ subject to $g=\tau\left(n_{H}+n_{M}\right)$ where $g_{i}^{H M}$ satisfies $A^{\prime}\left(g_{i}\right) k_{i} x=\frac{1}{n_{H}+n_{M}}$. If no one stands for election, the default policy is $g_{0}=0$ which yields $v_{i}(0)=\beta^{-1}$. At most one candidate from each group stands for election as long as the cost of running is positive. The entry game has four potential pure strategy equilibria: (A) a wealthy and a middle class capitalist enter, (B) only a wealthy capitalist enters, (C) only a middle class candidate enters, (D) no one enters. Since wealthy capitalists cannot win a contested election against a middle class candidate, simply because $n_{M}>n_{H}$, configuration (A) cannot be an equilibrium: the wealthy capitalist prefers not to run (same policy 
outcome, but no entry cost). Moreover, for small entry costs, configuration (D) cannot be an equilibrium either: each type of candidate prefers to enter and implement his most preferred policy to the default policy. Configuration (B) is an equilibrium if and only if

$$
\begin{aligned}
v_{M}\left(g_{H}^{H M}\right) & \geq v_{M}\left(g_{M}^{H M}\right)-\varepsilon_{M} \\
v_{H}\left(g_{0}\right) & \leq v_{H}\left(g_{H}^{H M}\right)-\varepsilon_{H} .
\end{aligned}
$$

Condition (15) fails for $\varepsilon_{M} \rightarrow 0^{+}$because $v_{M}\left(g_{M}^{H M}\right)>v_{M}\left(g_{H}^{H M}\right)$. Thus, this cannot be an equilibrium under Assumption (1). Configuration (C) is an equilibrium if and only if

$$
\begin{aligned}
v_{M}\left(g_{M}^{H M}\right)-\varepsilon_{M} & \geq v_{H}\left(g_{0}\right) \\
v_{H}\left(g_{M}^{H M}\right)-\varepsilon_{H} & \leq v_{H}\left(g_{M}^{H M}\right) .
\end{aligned}
$$

Both of these conditions are satisfied under Assumption (1).

Third, consider $H M L$-franchise. Suppose a capitalist of type $i$ is elected. He implements $g_{i}^{H M L}=\arg \max \pi_{i}^{*}(g)-2 \tau$ subject to $g=2 \tau\left(n_{H}+n_{M}\right)$ where $g_{i}^{H M L}$ satisfies $A^{\prime}\left(g_{i}\right) k_{i} x=\frac{1}{n_{H}+n_{M}}$. If no one stands for election, the default policy is $g_{0}=0$ which yields $v_{i}(0)=\beta^{-1}$. Worker candidates are never going to stand (Assumption 2) and at most one candidate from each of the other groups stands for election. While capitalists vote for a candidate of their own type, workers prefer a wealthy to a middle class capitalist. As above, only two of the four potential pure strategy equilibria are relevant. Configuration (B) is an equilibrium if and only if

$$
\begin{aligned}
v_{H}\left(g_{H}^{H M L}\right)-\varepsilon_{H} & \geq v_{H}\left(g_{0}\right) \\
v_{M}\left(g_{H}^{H M L}\right)-\varepsilon_{M} & \leq v_{M}\left(g_{H}^{H M L}\right) .
\end{aligned}
$$

Both of these conditions are satisfied under Assumption 1. Configuration (C) is an equilibrium if and only if

$$
\begin{aligned}
v_{H}\left(g_{H}^{H M L}\right)-\varepsilon_{H} & \leq v_{H}\left(g_{M}^{H M L}\right) \\
v_{M}\left(g_{M}^{H M L}\right)-\varepsilon_{M} & \geq v_{M}\left(g_{0}\right) .
\end{aligned}
$$

Condition (21) fails for $\varepsilon_{H} \rightarrow 0$ as $v_{H}\left(g_{H}^{H M L}\right)>v_{H}\left(g_{M}^{H M L}\right)$. The Proposition follows by setting $g_{H}^{H M L}=g_{L}$ and $g_{M}^{H M}=g_{M}$

Proposition 2. Since the middle class is worse off under $H M L$-franchise than under $H M$-franchise, an extension of the franchise from $H M$ - to $H M L$-franchise cannot be voluntary. Given that, $H M$-franchise is Pareto superior to $H$ franchise if and only if

$$
\begin{array}{rlrl}
(P S)^{M} & v_{M}\left(g_{M}\right) & >v_{M}\left(g_{H}\right) \\
(P S)^{H} & v_{H}\left(g_{M}\right) & >v_{H}\left(g_{H}\right) \\
(P S)^{L} & w\left(g_{M}\right) & >w\left(g_{H}\right)
\end{array}
$$

We prove the Proposition in three steps. First, rewrite $(P S)^{M}$ as follows

$$
x k_{M}\left(A\left(g_{M}\right)-A\left(g_{H}\right)\right)>\frac{g_{M}}{n_{M}+n_{H}}
$$


which can only be satisfied if $g_{H}<g_{M}$. Second, write $(P S)^{M}$ as in equation (26) and $(P S)^{H}$ as

$$
\left(A\left(g_{M}\right)-A\left(g_{H}\right)\right) x k_{H}+\frac{g_{H}}{n_{H}}>\frac{g_{M}}{n_{M}+n_{H}} .
$$

Since $(P S)^{M} \Rightarrow g_{M}>g_{H}, A^{\prime}>0$ and $k_{H}>k_{M}$, we have that $(P S)^{M} \Rightarrow(P S)^{H}$. Finally, since workers like $g$ to be as high as possible, they are better off under a $H M$-franchise than under a $H$-franchise if condition $(P S)^{M}$ is satisfied. Condition (9) then follows by rearranging condition $(P S)^{M}$. To prove the last part of the Proposition, it is sufficient to note that

$$
A\left(g_{M}\right) x k_{M}-\frac{g_{M}}{n_{M}+n_{H}}>A\left(g_{L}\right) x k_{M}-\frac{g_{L}}{n_{M}+n_{H}}
$$

from maximization

Proposition 3. An extension of the franchise from $H M$ - to $H M L$-franchise cannot be voluntary. Given that, $H M$-franchise is Pareto inferior to $H$ franchise if and only if

$$
\begin{array}{rrr}
(P I)^{M} & v_{M}\left(g_{M}\right)<v_{M}\left(g_{H}\right) \\
(P I)^{H} & v_{H}\left(g_{M}\right)<v_{H}\left(g_{H}\right) \\
(P I)^{L} & w\left(g_{M}\right)<w\left(g_{H}\right)
\end{array}
$$

We prove the Proposition in three steps. First, rewrite $(P I)^{H}$ as follows

$$
F\left(g_{M}, g_{H}\right)=x k_{H}\left(A\left(g_{H}\right)-A\left(g_{M}\right)\right)+\frac{g_{M}}{n_{M}+n_{H}}-\frac{g_{H}}{n_{H}}>0 .
$$

Notice that $F\left(g_{H}, g_{H}\right)<0$. Using equations (5) and (6), we can write the total differential of $F$ as

$$
d F=\frac{k_{M}-k_{H}}{\left(n_{H}+n_{M}\right) k_{M}} d g_{M} .
$$

It follows that $\frac{d F}{d g_{M}}<0$ and that if $F\left(g_{M}, g_{H}\right)>0$, then it must be that $g_{H}>g_{M}$. Second, write $(P I)^{M}$ as

$$
x k_{M}\left(A\left(g_{H}\right)-A\left(g_{M}\right)\right)+\frac{g_{M}}{n_{M}+n_{H}}>0
$$

Since $(P I)^{H} \Rightarrow g_{H}>g_{M}$ and $A^{\prime}>0$, we have that $(P I)^{H} \Rightarrow(P I)^{M}$. Finally, since workers like $g$ to be as high as possible, they are worse off under a $H M$-franchise than under a $H$-franchise if condition $(P S)^{H}$ is satisfied. The Proposition then follows by rearranging condition $(P S)^{H}$

\section{References}

[1] Acemoglu, Daron and James A. Robinson, "Why Did the West Extend the Franchise? Democracy, Inequality, and Growth in Historical Perspective," Quarterly Journal of Economics, 115 (2000), 1167-1199. 
[2] Aidt, Toke S., Jayasri Dutta and Elena Loukoianova, "Democracy Comes to Europe: Franchise Extension and Fiscal Outcomes 1830-1938," European Economic Review, 50 (2006), 249-283.

[3] Aidt, Toke S. and Peter Jensen, "Taxation and the Extension of the Voting Franchise in Western Europe, 1860-1938," International Tax and Public Finance (In press).

[4] Aidt, Toke S. and Peter Jensen, "The Taxman Tools Up: An Event History Study of the Introduction of the Personal Income Tax in Western Europe, 1815-1941," Faculty of Economics, University of Cambridge, Cambridge Working Papers in Economics 0766 (2007).

[5] Bardhan, Pranab, "Capture and Governance at Local and National Levels," American Economic Review, 90(2) (2000), 135-139.

[6] Bardhan, Pranab, "Decentralization of Governance and Development," Journal of Economic Perspectives, 16 (2002), 185-205.

[7] Beck, Nathaniel and Jonathan Katz, "What to Do (and Not to Do) with Time-Series Cross-Section Data," American Political Science Review, 89(3) (1995), 634-47.

[8] Bell, Frances and Robert Millward, "Public Health Expenditures and Mortality in England and Wales, 1870-1914," Continuity and Change, 13(2) (1998), 221-249.

[9] Besley, Timothy and Stephen Coate, "An Economic Model of Representative Democracy," Quarterly Journal of Economics, 112(1) (1997), 85-114.

[10] Chattopadhyay, Raghabendra and Esther Duflo, "Women as Policy Makers: Evidence From a Randomized Policy Experiment in India," Econometrica, 72 (2004), 1409-1443.

[11] Congleton, Roger D., "Economic Development and Democracy, Does Industrialization Lead to Universal Suffrage? Homo Economicus, 21 (2004), 283-311.

[12] Conley, John P. and Akram Temini, "Endogenous Enfranchisement When Groups' Preferences Conflict" Journal of Political Economy, 109(1) (2001), 79-102.

[13] Daunton, Martin, Trusting Leviathan: The Politics of Taxation in Britain, 1799-1914 (Cambridge, UK:Cambridge University Press, 2001).

[14] Davis, John. and D. Tanner, "The Borough Franchise after 1867," Historical Research, 69 (1996), 306-327.

[15] Davis, John, "Central Government and the Towns," pp. 261-286, in Martin Daunton, ed., The Cambridge Urban History of Britain vol. III, 1840-1950 (Cambridge, UK: Cambridge University Press, 2001). 
[16] Doyle, Barry M., "The Changing Functions of Urban Government: Councillors, Official and Pressure Groups," pp. 287-314, in Martin Daunton, ed., The Cambridge Urban History of Britain vol. III, 1840-1950 (Cambridge, UK: Cambridge University Press, 2001).

[17] Engerman, Stanley L. and Kenneth L. Sokoloff, "The Evolution of Suffrage Institutions in the New World." Journal of Economic History, 65 (2005), 891-921.

[18] Fraser, Derek, Urban politics in Victorian England, (Leicester, UK: Leicester University Press, 1976).

[19] Hennock, Ernest P., "Finance and Politics in Urban Local Government in England, 1835-1900," History Journal, 6 (1963).

[20] Hennock, Ernest P., Fit and Proper Persons: Ideals and Reality in Nineteenth-century Urban Government (Edward Arnold: London, 1973).

[21] Husted, Thomas A. and Lawrance W. Kenny, "The Effect of the Expansion of the Voting Franchise on the Size and Scope of Government," Journal of Political Economy, 105 (1997), 54-82.

[22] Justman, Moshe and Mark Gradstein, "The Industrial Revolution, Political Transition, and the Subsequent Decline in Inequality in 19th-century Britain," Explorations in Economic History, 36 (1999), 109-127.

[23] Keith-Lucas, Brian, The English Local Government Franchise. A Short History (Oxford, UK: Basil Blackwell, 1952).

[24] Lindahl, Erik. "Die Gerechtigkeit der Besteurung, Positive Lösung (Just Taxation - A positive Solution)", pp.168-176. Reprinted and translated in Richard A. Musgrave and Alan T. Peacock (eds.) Classics in the Theory of Public Finance (London, MacMillan \& Co, 1964).

[25] Lindert, Peter H., "The Rise in Social Spending 1880-1930," Explorations in Economic History, 31 (1994), 1-37.

[26] Lindert, Peter H., Growing Public, Social Spending and Economic Growth Since the Eighteenth Century (Cambridge, UK: Cambridge University Press, 2004a).

[27] Lindert, Peter H., Growing Public, Further Evidence (Cambridge, UK: Cambridge University Press, 2004b).

[28] Lizzeri, Alessandro and Nicola Persico, "Why Did the Elites Extend the Suffrage? Democracy and the Scope of Government, with an Application to Britain's "Age of Reform"," Quarterly Journal of Economics, 119(2) (2004), 707-765.

[29] Lott, John R., and Lawrance W. Kenny, "Did Women's Suffrage Change the Size and Scope of Government?," Journal of Political Economy, 107 (1999), 1163-1198. 
[30] Matthew, H. C. G., R. I. McKibbin and J. A. Kay, "The Franchise Factor in the Rise of the Labour Party," The English Historical Review, 91(361) (1976), 723-752.

[31] Meltzer, A.H., Richard S.F, "A Rational Theory of the Size of Government." Journal of Political Economy, 89(5) (1981.), 914-27.

[32] Millward, Robert and Sally Sheard, "The Urban Fiscal Problem, 1870-1914: Government Expenditures and Finance in England and Wales," Economic History Review, 48(3) (1995), 501-535.

[33] Millward, Robert, "The Political Economy of Urban Utilities," pp 315-350, in Martin Daunton, ed., The Cambridge Urban History of Britain vol. III, 1840-1950 (Cambridge, UK: Cambridge University Press, 2001).

[34] Mulligan, Casey, B., Richard Gil and Xavier Sala-i-Martin, "Social Security and Democracy" National Bureau of Economic Research Working Paper Series no. 8958 (Cambridge, MA: National Bureau of Economic Research, 2002).

[35] Offer, Avner, Property and Politics, 1870-1914: Landownership, Law, Ideology and Urban Development in England (Cambridge, UK: Cambridge University Press, 1981).

[36] Osborne, Martin J. and Al Slivinski, "A Model of Political Competition with CitizenCandidates," Quarterly Journal of Economics, 111(1) (1996), 65-96.

[37] Santos, Boaventura de Sausa, "Participatory Budgeting in Porto Alegre: Toward a Redistributive Democracy," Politics and Society, 26(4) (1998), 461-510.

[38] Smellie, Kingsley B. A History of Local Government (London: Allen \& Unwin, 1946).

[39] Stigler, George J., "Director's Law of Public Income Redistribution," Journal of Law and Economics, 13(1) (1970), 1-10.

[40] Szreter, Simon, "The Importance of Social Intervention in Britain's Mortality Decline 1850-1914: a Reinterpretation of the Role of Public Health," Social History of Medicine, I (1988), 1-37.

[41] Szreter, Simon, "Economic Growth, Disruption, Deprivation, Disease, and Death: On the Importance of the Politics of Public Health for Development," Population and Development Review, 23(4) (1997), 693-728.

[42] Szreter, Simon and Graham Mooney, "Urbanization, Mortality, and the Standard of Living Debate: New Estimates of the Expectation of Life at Birth in Nineteenthcentury British Cities" Economic History Review, 51(1) (1998), 84-112.

[43] Waller, Philip J. Town, City and Nation, England 1850-1914 (Oxford, UK: Oxford University Press, 1983). 
[44] Williamson, Jeffrey G. Coping With City Growth During the British Industrial Revolution (Cambridge, UK: Cambridge University Press, 1990).

[45] Wohl, Anthony S. Endangered lives: Public health in Victorian Britain (London: Dent, 1983).

[46] Wooldridge, Jeffrey, M. Econometric Analysis of Cross Section and Panel Data (Cambridge, MA: MIT Press, 2002). 


\section{Extra material}

\section{Not intended for publication}

\section{$9 \quad$ Extra Appendix I}

A fully extended franchise includes workers. Since the middle class, once they have got the vote, loses from further extensions of the franchise, voluntary enfranchisement of the working class can only take place through a direct extension from $H$ - to $H M L$-franchise.

Proposition 4 (Voluntary enfranchisement of the middle and working class) HML-franchise is Pareto superior to $H$-franchise if and only if

$$
x k_{M}\left(A\left(g_{L}\right)-A\left(g_{H}\right)\right)>2 \tau_{L} .
$$

Voluntary enfranchisement of the middle and working class is associated with an increase in spending on local public goods.

Proof. $H M L$-franchise is Pareto superior to $H$-franchise if and only if

$$
\begin{array}{rrr}
(P S D)^{M} & v_{M}\left(g_{L}\right)>v_{M}\left(g_{H}\right) \\
(P S D)^{H} & v_{H}\left(g_{L}\right)>v_{H}\left(g_{H}\right) \\
(P S D)^{L} & w\left(g_{L}\right)>w\left(g_{H}\right) .
\end{array}
$$

Begin by noting that $g_{L}>g_{H}$ so that $(P S D)^{L}$ is satisfied. Write $(P S D)^{M}$ as

$$
x k_{M}\left[A\left(g_{L}\right)-A\left(g_{H}\right)\right]>\frac{g_{L}}{n_{H}+n_{M}}
$$

and $(P S D)^{H}$ as

$$
x k_{H}\left[A\left(g_{L}\right)-A\left(g_{H}\right)\right]+\frac{g_{H}}{n_{H}}>\frac{g_{L}}{n_{H}+n_{M}} .
$$

Since $k_{H}>k_{M}$ and $g_{L}>g_{H}$, it follows that $(P S D)^{M} \Rightarrow(P S D)^{H}$

Enfranchisement of the middle and working class is voluntary if and only if the middle class is willing to accept the franchise, as this guarantees that the elite and workers also gain. This requires that the benefit associated with the extra spending on local public goods dominates the cost of having to pay the rates, both on their own house and, through compounding, on the accommodation they let in the market. Assuming that $A(g)=\frac{1}{\gamma} g^{\gamma}$, we can rewrite equation (35) to note that voluntary enfranchisement of the middle and working class is only possible if $\frac{k_{H}}{k_{M}}<\frac{1}{\gamma}$ and

$$
\frac{n_{M}+n_{H}}{n_{H}}>\left(1-\frac{k_{H}}{k_{M}} \gamma\right)^{\frac{\gamma-1}{\gamma}} .
$$

Intuitively, enfranchisement of the middle and working class is a Pareto improvement if the middle class is relatively large such that the burden of higher spending can be shared among more ratepayers and wealth inequality is low. In fact, in cities with sufficiently high wealth inequality $\left(\frac{k_{H}}{k_{M}}>\frac{1}{\gamma}\right)$ enfranchisement of the middle and working class at the same time cannot be voluntary. 


\section{Extra Appendix II: Tax Incidence}

In the main text, we consider the case where workers live in rented accommodation and the incidence of the rate, if applicable, falls on the landlord (short run). In this appendix, we show that the results are qualitatively the same if we make the opposite assumption, namely that the incidence of the tax on the property of workers falls entirely on them (long run). To this end, we assume that workers own the house they live in (or alternatively that the supply of housing is infinitely elastic). The rest of the model is the same.

\subsection{Retrenchment}

The equilibrium analysis under $H$ - and $H M$-franchise is as before with spending determined by

$$
A^{\prime}\left(g_{H}\right) x k_{H}=\frac{1}{n_{H}}
$$

and

$$
A^{\prime}\left(g_{M}\right) x k_{M}=\frac{1}{n_{H}+n_{M}} .
$$

Under $H M L$-franchise, workers are going to vote for the candidate with the platform closest to their ideal spending policy. They know that a $H$-candidate will spend more than a $M$-candidate. Since we assume that $z<x k_{M}$, workers want less spending, for a given tax base, than any of the capitalists. They, accordingly, support that middle class candidate. Knowing that a middle class candidate runs and gets elected. He implements

$$
A^{\prime}\left(g_{L}\right) x k_{M}=\frac{1}{n_{L}+n_{H}+n_{M}} .
$$

It is clear that the retrenchment hypothesis is true whenever

$$
\frac{k_{H}}{k_{M}}>\frac{n_{M}+n_{H}}{n_{H}}
$$

as in the short run. To see this note that $g_{L}>g_{M}$ because of the tax base effect associated with the extension of the franchise to workers. Thus, in the short run, spending goes up when the working class is enfranchised because of the cross class alliance between the elite and the working class. In the long run, spending goes up because the middle class gain access to a larger tax base.

\subsection{Voluntary or Forced Enfranchisement}

The key difference between the short and long run is the fact that the move from $H M$ franchise to $H M L$-franchise can be voluntary in the long run, i.e., supported by all three groups. When considering the extension from $H$ - to $H M$-franchise agents anticipate that further voluntary extension might happen. Moreover, we might observe that the middle class is always better off under $H M L$-franchise than under $H M$-franchise: it keeps control 
over the council but has a larger tax base. This implies that $H M L$-franchise cannot be Pareto inferior to $H M$-franchise.

We begin with the proposition determining when voluntary enfranchisement of the middle class is possible.

Proposition 5 (Voluntary enfranchisement of the middle class). HM-franchise is Pareto superior to $H$-franchise if

$$
\left[A\left(g_{M}\right)-A\left(g_{H}\right)\right] x k_{M}>\frac{g_{M}}{n_{M}+n_{H}}
$$

and

$$
\frac{g_{L}}{n_{M}+n_{H}+n_{L}}>\left[A\left(g_{L}\right)-A\left(g_{M}\right)\right] z
$$

A voluntary extension of the franchise to the middle class is always associated with an increase in spending on local public goods. Moreover, once HM-franchise has been granted, enfranchisement of the working class cannot be voluntary.

Proof. Suppose that $H M$-franchise has been reached. Workers will not agree to further extensions when

$$
A\left(g_{M}\right) z>A\left(g_{L}\right) z-\frac{g_{L}}{n_{M}+n_{H}+n_{L}} .
$$

Given that, the analysis of the welfare implications of an extension from $H$ - to $H M$ franchise are as in the short run

We note that condition (47) might not hold, i.e., workers might like to pay taxes despite the fact that they do not gain control of the council. This can obviously only happen if the level of spending under $H M$-franchise is below what they would have liked to spend had they gained control of the council under $H M L$-franchise:

$$
A^{\prime}\left(g_{L}^{W}\right) z=\frac{1}{n_{L}+n_{H}+n_{M}} .
$$

Clearly, $g_{L}^{W}<g_{L}$, so it is only in the interest of workers to accept paying taxes if $g_{L}$ is sufficiently close to $g_{L}^{W}$ and $g_{M}$ is sufficiently below this. In this case, paying taxes will be more than compensated for by the fact that spending moves closer to workers' ideal spending level. With $A(g)=\frac{1}{\gamma} g^{\gamma}$, we can write condition (47) as

$$
\frac{1-\alpha}{\alpha}>\left(1-\left(\frac{n_{H}+n_{M}}{n_{H}+n_{M}+n_{L}}\right)^{\frac{\gamma}{1-\gamma}}\right) \frac{n_{M}+n_{H} \frac{k_{H}}{k_{M}}}{\gamma n_{L}}=F\left(n_{H}, n_{M}, k_{M}, k_{H}\right) .
$$

The condition that $z<x$ implies that

$$
\frac{1-\alpha}{\alpha}>\frac{n_{M}+n_{H} \frac{k_{H}}{k_{M}}}{n_{L}}
$$


So it is possible that condition (47) fails, even when $\frac{1-\alpha}{\alpha}>\frac{n_{M}+n_{H} \frac{k_{H}}{k_{M}}}{n_{L}}$.

With regard to forced enfranchisement of the middle class, we get the following long run result.

Proposition 6 (Forced enfranchisement of the middle class) HM-franchise is Pareto inferior to $H$-franchise if

$$
x k_{H}\left(A\left(g_{H}\right)-A\left(g_{M}\right)\right)>\frac{g_{H}}{n_{H}}-\frac{g_{M}}{n_{H}+n_{M}} .
$$

and

$$
\frac{g_{L}}{n_{M}+n_{H}+n_{L}}>\left[A\left(g_{L}\right)-A\left(g_{M}\right)\right] z
$$

A forced extension of the franchise to the middle class is always associated with a reduction in spending on local public goods and once it has been forced upon the middle class no further (voluntary) extension will take place.

Proof. Suppose that $H M$-franchise has been reached. Workers will not agree to further extensions when

$$
A\left(g_{M}\right) z>A\left(g_{L}\right) z-\frac{g_{L}}{n_{M}+n_{H}+n_{L}} .
$$

Given that, the analysis of the welfare implications of an extension from $H$ - to $H M$ franchise are as in the short run

As discussed above, in the long run a 2-step voluntary enfranchisement process is a possibility.

Proposition 7 (2-step voluntary enfranchisement of the working class). HM-franchise is Pareto superior to $H$-franchise and $H M L$-franchise is Pareto superior to $H M$-franchise if

$$
\left(A\left(g_{L}\right)-A\left(g_{M}\right)\right) z>\frac{g_{L}}{n_{H}+n_{M}+n_{L}}
$$

and

$$
\left(A\left(g_{L}\right)-A\left(g_{H}\right)\right) z>\frac{g_{L}}{n_{H}+n_{M}+n_{L}} .
$$

Proof. Suppose $H M$-franchise has been reached. It will be extended to $H M L$-franchise if all three parties agree. Notice that the middle class always agree and that if the working class agrees, then the elite agrees as well, i.e.,

$$
A\left(g_{L}\right) z-\frac{g_{L}}{n_{H}+n_{M}+n_{L}}>A\left(g_{M}\right) z
$$

implies

$$
A\left(g_{L}\right) x k_{H}-\frac{g_{L}}{n_{H}+n_{M}+n_{L}}>A\left(g_{M}\right) x k_{H}-\frac{g_{M}}{n_{H}+n_{M}} .
$$


Thus, suppose that condition (56) holds, then $H M L$-franchise Pareto dominates $H M$ franchise. Anticipating this, a voluntary extension from $H$ to $H M$ requires that all three groups prefer $H M L$-franchise to $H$-franchise or

$$
\begin{gathered}
\left(A\left(g_{L}\right)-A\left(g_{H}\right)\right) z>\frac{g_{L}}{n_{H}+n_{M}+n_{L}} \\
\left(A\left(g_{L}\right)-A\left(g_{H}\right)\right) x k_{M}>\frac{g_{L}}{n_{H}+n_{M}+n_{L}} \\
\left(A\left(g_{L}\right)-A\left(g_{H}\right)\right) x k_{H}+\frac{g_{H}}{n_{H}}>\frac{g_{L}}{n_{H}+n_{M}+n_{L}}
\end{gathered}
$$

where it is clear that condition (58) implies conditions (59) and (60)

\section{Extra Appendix II: Robustness}

Tables $B 1$ and $B 2$ report results from an extensive robustness analysis. With a few exceptions, we report the results from specifications with borough and time fixed effects. Similar, and often stronger, results emerge from the specification with shire-specific trends.

[Tables $B 1$ and $B 2$ to appear here.]

Additional Controls Regressions (1) to (4) of Table $B 1$ show that our results are robust to the inclusion of two additional control variables. Firstly, the Corporations did have other sources of income than the rate. In particular, in some boroughs trading profits and income from markets and harbours were substantial. To test if availability of other sources of income than the rates affects investments in urban amenities, we include in regressions (1) and (2) a measure of the fraction of the budget derived from profits and rents (budget share of rents and profits). The measure itself is insignificant and has minimal impact on the parameters of interest. Secondly, the rate at which the boroughs were physically expanding might have affected investments in urban amenities because of changing needs, but also because an expansion of the stock of housing often affected how the incidence of the rate levied on rented accommodation was divided between tenant and landlord. To test this hypothesis, we include in regressions (3) and (4) a measure of the growth rate of the stock of houses over the previous 10 years. Although the impact is positive and significant in one of the specifications, the parameters of interest are unaffected. ${ }^{57}$ Finally, above we control for shire-specific trends, not for borough-specific trends. The reason is that we would have very few degrees of freedom left if we included 55 borough-specific trends. However, as regressions (5) and (6) show, the results with borough-specific trends are consistent with the retrenchment hypothesis and not all that different from the results with shire-specific trends. ${ }^{58}$

\footnotetext{
${ }^{57} \mathrm{~A}$ similar result obtains if we use population growth instead (not reported).

${ }^{58}$ In our sample, 33 shires are represented and at most 10 boroughs are located in the same shire.
} 
Fiscal Lags It is unlikely that an extension of the voting franchise has an immediate impact on fiscal outcomes. New councilors need to be elected and although a third of the elected members were up for election each year, it would take at least two years after an extension of the franchise before a majority of councilors were elected under the new franchise. As it happens, the regression reported above partially takes such fiscal lags into account because of the imperfect overlap between the timing of our cross sections of data on the total number of voters $(1865,1871,1884)$ and our cross sections of fiscal data $(1868$, 1871 and 1886). However, we can allow for even longer fiscal lags by using fiscal data from 1875 and 1888 instead of data from 1871 and 1886. Regressions (7) and (8) show that longer fiscal lags reduces the turning point to around 32 per cent and makes it harder, in particular in the specification with borrowed funds, to estimate $\alpha_{1}$ precisely.

Balanced Panel Our panel is unbalanced with 55 boroughs and 2.3 observations on average per borough. By balancing the panel, we reduce the number of observations to 48 with only 16 boroughs. It is, therefore, somewhat surprising that the retrenchment effect comes through even stronger for this sub-sample and that the turning point continues to be around 40 per cent (see regressions (9) and (10) in Table B1).

General-to-Specific The regression results reported in Tables 4 and 5 include many insignificant control variables. This reduces the degrees of freedom and may cause problems of multicollinearity. It is, therefore, of interest to ask what happens if we exclude insignificant control variables from the analysis. To this end, we adopt a general-to-specific approach and eliminate iteratively the most "insignificant" variable, keeping shire-specific trends and time fixed effects if those are jointly significant. The results are shows in Table $B 1$, regressions (11) to (13). In the specification with spending on urban amenities, we see that industrial employment, rateable value and accumulated debt are significant. In the specification with borrowed funds, none of the control variables are significant if we keep the sample constant as we test the model down, but rateable value and accumulated debt are significant if we allow the sample to expand as we exclude variables. In all cases, the evidence continues to support the retrenchment hypothesis, with a turning point around 40 per cent.

Clustered Standard Errors and Serial Correlation In all the regressions (except in the Tobit and in the median regression model), the reported standard errors are robust to arbitrary heteroskedasticity. In addition to this, we can allow the standard errors to be robust to correlations between the error terms within clusters (boroughs) and to arbitrary serial correlation. The results are shown in Table B2, regressions (14) to (21). We see that our basic results are robust to these corrections. The only case in which the significance of $\alpha_{1}$ drops below the 10 per cent level is in regression (15) with clustered the error terms. Significance is, however, regained when insignificant fixed time effects are excluded (regression (16)). 
Random Effects Estimates We have focused on the fixed effects estimator because we a priori have strong reasons to believe that the unobserved fixed effects are correlated with our measure of the franchise. If so, the random effects estimator is inconsistent. In turns out, however, that the Hausman test does not reject the random effects model, as illustrated by regressions (22) to (24). While the evidence from the random effects estimator supports the retrenchment hypothesis, we have more confidence in the fixed effects estimates. Finally, the random effects model uses "between" as well as "within" variation to identify the retrenchment effect. We notice from regressions (25) and (26), which show what happen when the three cross sections are time averaged (the "between" estimator) that although the signs are correct, the retrenchment effect cannot be identified from the cross sectional variation alone. ${ }^{59}$ It is the fact that we observe boroughs over time that identifies the retrenchment effect.

Tobit Estimates Some boroughs did not spend anything on urban amenities or borrowed any funds for investments in urban amenities in some years (see Table A1 in Appendix). This creates a potential corner solution problem, which may call for the adoption of a censored Tobit model..$^{60}$ In regressions (27) and (28), we report the results from such a model. The evidence continues to support the retrenchment hypothesis, although the turning point is somewhat lower (36-38 per cent).$^{61}$

\footnotetext{
${ }^{59} \mathrm{~A}$ similar message comes from seperate cross sectional regressions (not reported).

${ }^{60}$ See Wooldridge (2002, chapter 16).

${ }^{61}$ The reported marginal effects should be corrected for the probability that the latent variable is above 0 evaluated at the mean of the explanatory variables. As this correction is very small and it does not affect the calculation of the turning point, we do not report it.
} 
Table 1: The extension of the voting franchise for the Municipal Corporations in 1852, 1865, 1871 and 1884.

\begin{tabular}{|c|c|c|c|c|c|}
\hline & $\begin{array}{c}\text { Number } \\
\text { of } \\
\text { boroughs }\end{array}$ & Mean & $\begin{array}{c}\text { Standard } \\
\text { deviation. }\end{array}$ & minimum & maximum \\
\hline Year & & & & & \\
\hline 1852 & 33 & 28.6 & 11.0 & 11.4 & 52.3 \\
\hline 1865 & 63 & 35.6 & 14.0 & 11.5 & 81.9 \\
\hline 1871 & 73 & 57.0 & 12.8 & 28.2 & 81.9 \\
\hline 1884 & 75 & 64.2 & 10.8 & 33.0 & 86.7 \\
\hline $\begin{array}{c}\text { All } \\
\text { years }\end{array}$ & 244 & 49.8 & 18.5 & 11.4 & 86.7 \\
\hline
\end{tabular}

Source: British Parliamentary Papers (see Data Appendix for further details).

Notes: The franchise is measured as the total number of registered voters in per cent of all male inhabitants, aged above 20 , in the borough.

Table 2: Average spending on urban amenities and borrowed funds, 1868-1888.

\begin{tabular}{|c|c|c|c|c|c|c|c|c|c|}
\hline & $\begin{array}{c}\text { Number } \\
\text { of } \\
\text { boroughs }\end{array}$ & \multicolumn{2}{|c|}{$\begin{array}{c}\text { Spending on urban } \\
\text { amenities/total } \\
\text { spending }\end{array}$} & \multicolumn{2}{c|}{$\begin{array}{c}\text { Spending on } \\
\text { urban amenities } \\
\text { per 1000 capita }\end{array}$} & \multicolumn{2}{c|}{$\begin{array}{c}\text { Borrowed } \\
\text { funds/total } \\
\text { revenue }\end{array}$} & \multicolumn{2}{c|}{$\begin{array}{c}\text { Borrowed funds } \\
\text { per 1000 capita }\end{array}$} \\
\hline Year & & $\%$ & St. dev. & $\%$ & St. dev. & $£$ & St. dev. & $£$ & St. dev. \\
\hline 1868 & 68 & 44.8 & 17.4 & 14.9 & 18.4 & 189.3 & 319.6 & 398.6 & 355.9 \\
\hline 1871 & 74 & 45.7 & 14.2 & 17.7 & 19.9 & 284.7 & 550.1 & 453.2 & 451.6 \\
\hline 1875 & 74 & 47.9 & 13.1 & 18.3 & 19.3 & 434.2 & 754.2 & 758.7 & 817.9 \\
\hline 1886 & 75 & 50.5 & 12.5 & 17.9 & 17.9 & 410.2 & 708.0 & 887.4 & 779.1 \\
\hline 1888 & 75 & 48.8 & 11.1 & 15.1 & 16.4 & 360.0 & 828.1 & 850.9 & 857.5 \\
\hline
\end{tabular}

Source: British Parliamentary Papers (see Data Appendix for further details).

Notes: The data refers to the aggregates of the accounts of the Corporations and the Local Boards (1868 and 1871$)$ and the Urban Sanitary Authorities (1875, 1886 and 1888). Spending on urban amenities includes spending on sewage, water supply, gas supply, streets and other similar public works. Borrowed funds are the sums of monies raised on security of the rates during the year. 
Table 3: The franchise and spending on urban amenities in the 21 boroughs, 1871 .

\begin{tabular}{|c|c|c|c|c|c|c|}
\hline \multirow[t]{3}{*}{ Borough } & \multirow{2}{*}{\multicolumn{2}{|c|}{$\begin{array}{c}\text { Voters in } \% \text { of } \\
\text { total } \\
\text { adult male } \\
\text { population }\end{array}$}} & \multicolumn{2}{|c|}{$\begin{array}{l}\text { Income from the } \\
\text { rates per } 1000 \\
\text { capita }\end{array}$} & \multicolumn{2}{|c|}{$\begin{array}{l}\text { Spending on } \\
\text { urban amenities per } \\
1000 \text { capita }\end{array}$} \\
\hline & $\%$ & & \multicolumn{2}{|c|}{$£$} & \multicolumn{2}{|c|}{$£$} \\
\hline & & $\begin{array}{l}\text { Group } \\
\text { means }\end{array}$ & & $\begin{array}{l}\text { Group } \\
\text { Means }\end{array}$ & & $\begin{array}{l}\text { Group } \\
\text { means }\end{array}$ \\
\hline Newcastle (upon Tyne) & 36.9 & & 415.8 & & 893.8 & \\
\hline Liverpool & 41.7 & & 659.0 & & 416.1 & \\
\hline Ipswich & 46.9 & & 282.8 & & 342.1 & \\
\hline Southampton & 48.9 & & 611.6 & & 248.8 & \\
\hline Gloucester & 49.9 & & 638.8 & & 406.2 & \\
\hline Reading & 53.6 & & 514.6 & & 768.3 & \\
\hline Sheffield & 54.3 & 47.4 & 323.4 & 492.3 & 194.8 & 467.2 \\
\hline Bedford & 55.6 & & 610.3 & & 395.9 & \\
\hline Bath & 56.1 & & 491.1 & & 377.8 & \\
\hline Exeter & 56.6 & & 461.7 & & 233.5 & \\
\hline Wigan & 57.0 & & 800.7 & & 322.1 & \\
\hline Preston & 57.8 & & 591.1 & & 383.8 & \\
\hline Birmingham & 60.0 & & 403.9 & & 248.5 & \\
\hline Macclesfield & 61.2 & 57.7 & 252.4 & 515.9 & 280.7 & 320.3 \\
\hline Bradford & 61.7 & & 1166.6 & & 1668.4 & \\
\hline Stockport & 66.4 & & 384.1 & & 265.1 & \\
\hline York & 67.0 & & 337.8 & & 227.6 & \\
\hline \begin{tabular}{|l|} 
Leeds \\
\end{tabular} & 68.7 & & 1070.0 & & 1365.2 & \\
\hline Coventry & 74.3 & & 274.7 & & 218.2 & \\
\hline Gateshead & 76.4 & & 420.6 & & 420 & \\
\hline Manchester & 79.9 & 70.6 & 568.0 & 603.1 & 648.5 & 687.6 \\
\hline
\end{tabular}

Source: British Parliamentary Papers (see Data Appendix for further details).

Note: The groups means refer to the average for the boroughs listed in or above the row where the figure appears. 
Table 4: Results for spending on urban amenities per (1000) capita.

\begin{tabular}{|c|c|c|c|c|c|}
\hline & $(1)$ & $(2)$ & (3) & $(4)$ & $(5)$ \\
\hline \multirow[t]{2}{*}{ Estimation method $^{\mathrm{a}}$} & Within & Within & Within & Pooled & Pooled \\
\hline & OLS & OLS & OLS & OLS & Median \\
\hline \multirow[t]{2}{*}{ Franchise } & $-28.0 * *$ & $-26.8 *$ & $-71.7 * * *$ & $-17.9 *$ & $-16.1^{*}$ \\
\hline & {$[1.96]$} & [1.65] & {$[4.15]$} & {$[1.89]$} & {$[1.97]$} \\
\hline \multirow[t]{2}{*}{ Franchise squared } & $0.35 * *$ & $0.36^{*}$ & $0.83 * * *$ & $0.22 * *$ & $0.17 * *$ \\
\hline & {$[2.08]$} & [1.89] & {$[4.95]$} & [2.29] & {$[2.18]$} \\
\hline \multirow[t]{2}{*}{ Population } & -0.004 & -0.003 & 0.006 & -0.001 & $-0.001 *$ \\
\hline & {$[0.90]$} & [0.49] & {$[0.87]$} & {$[1.31]$} & {$[1.86]$} \\
\hline \multirow[t]{2}{*}{ Industrial employment } & -2.6 & -7.7 & -3.5 & $15.5 * * *$ & $10.3 * * *$ \\
\hline & {$[0.17]$} & {$[0.37]$} & {$[0.14]$} & {$[4.32]$} & {$[4.02]$} \\
\hline \multirow[t]{2}{*}{ Rateable value } & -0.0003 & -0.02 & 0.39 & $0.19 * * *$ & $0.15 * * *$ \\
\hline & {$[0.00]$} & {$[0.08]$} & [1.37] & {$[3.26]$} & {$[2.93]$} \\
\hline \multirow[t]{2}{*}{ Population density } & -3.26 & -3.94 & -4.33 & -0.23 & -0.31 \\
\hline & {$[0.75]$} & {$[0.95]$} & {$[0.66]$} & {$[0.91]$} & {$[1.16]$} \\
\hline \multirow[t]{2}{*}{ Accumulated debt } & $0.26 * * *$ & $0.25 * * *$ & $0.18^{* *}$ & $0.19 * * *$ & $0.17 * * *$ \\
\hline & {$[4.04]$} & {$[3.84]$} & {$[2.08]$} & {$[4.88]$} & {$[5.87]$} \\
\hline Turning point $^{\mathrm{e}}$ & 40.0 & 37.2 & 43.2 & 40.7 & 47.4 \\
\hline Regional fixed effects & no & no & no & yes & yes \\
\hline$\chi^{2}$ test $(p \text {-value })^{b}$ & & & & 0.00 & 0.13 \\
\hline Time fixed effects & no & yes & yes & yes & yes \\
\hline$\chi^{2}$ test $(p-v a l u e)^{c}$ & & 0.88 & 0.14 & 0.16 & 0.00 \\
\hline Shire-specific trends & no & no & yes & no & no \\
\hline$\chi^{2}$ test $(\mathrm{p} \text {-value })^{\mathrm{d}}$ & & & 0.02 & & \\
\hline Observations & 127 & 127 & 127 & 141 & 141 \\
\hline Boroughs & 55 & 55 & 55 & 69 & 69 \\
\hline
\end{tabular}

Notes: $\mathrm{Z}$ statistics in brackets (robust to arbitrary heteroskedasticity, except in (6)); * significant at $10 \%$; ** significant at $5 \%$; *** significant at $1 \%$; a) Regressions (5) and (6) include a constant; b) $\chi^{2}$ test: The null is that all regional fixed effects are $0 ;$ c) $\chi^{2}$ test: The null is that all time fixed effects are $0 ;$ d) $\chi^{2}$ test: The null is that all shire-specific trends are 0 ; e) Turning point $=-\hat{\alpha}_{1} / 2 \hat{\alpha}_{2}$. 
Table 5: Results for borrowed funds per (1000) capita.

\begin{tabular}{|c|c|c|c|c|c|}
\hline & $(6)$ & (7) & $(8)$ & $(9)$ & $(10)$ \\
\hline & & & & & \\
\hline \multirow[t]{2}{*}{ Estimation method $^{\mathrm{a}}$} & Within & Within & Within & Pooled & Pooled \\
\hline & OLS & OLS & OLS & OLS & Median \\
\hline \multirow[t]{2}{*}{ Franchise } & $-40.0^{*}$ & $-44.5^{*}$ & $-125.5 * * *$ & $-29.4 * *$ & $-9.8 * *$ \\
\hline & {$[1.78]$} & {$[1.71]$} & {$[5.57]$} & {$[2.14]$} & {$[2.24]$} \\
\hline \multirow[t]{2}{*}{ Franchise squared } & $0.50 *$ & $0.56^{*}$ & $1.40 * * *$ & $0.35 * *$ & $0.09 * *$ \\
\hline & {$[1.86]$} & {$[1.87]$} & {$[6.36]$} & {$[2.43]$} & [2.23] \\
\hline \multirow[t]{2}{*}{ Population } & -0.004 & 0.001 & $0.019 * *$ & 0.001 & $0.001 * * *$ \\
\hline & {$[0.63]$} & [0.22] & {$[2.15]$} & {$[0.77]$} & {$[3.84]$} \\
\hline \multirow[t]{2}{*}{ Industrial employment } & $44.0 * *$ & 22.4 & 27.5 & $14.0 * * *$ & $5.78 * * *$ \\
\hline & {$[2.33]$} & {$[0.85]$} & {$[0.83]$} & {$[2.90]$} & {$[4.03]$} \\
\hline \multirow[t]{2}{*}{ Rateable value } & 0.30 & 0.33 & 0.44 & 0.11 & $0.06^{* *}$ \\
\hline & {$[0.60]$} & {$[0.65]$} & [1.19] & {$[1.15]$} & {$[2.08]$} \\
\hline \multirow[t]{2}{*}{ Population density } & -4.7 & -7.7 & -12.7 & -0.20 & -0.19 \\
\hline & {$[0.98]$} & {$[1.51]$} & {$[1.48]$} & {$[0.63]$} & {$[1.10]$} \\
\hline \multirow[t]{2}{*}{ Accumulated debt } & $0.27 * * *$ & $0.28 * * *$ & $0.21 *$ & 0.11 & $0.05 * * *$ \\
\hline & {$[2.70]$} & {$[2.60]$} & {$[1.88]$} & {$[1.41]$} & {$[3.00]$} \\
\hline Turning point $^{\mathrm{e}}$ & 40.0 & 39.7 & 44.8 & 42.0 & 52.7 \\
\hline Regional fixed effects & no & no & no & yes & yes \\
\hline$\chi^{2}$ test $(p \text {-value })^{b}$ & & & & 0.04 & 0.34 \\
\hline Time fixed effects & no & yes & yes & yes & yes \\
\hline$\chi^{2}$ test $(p-v a l u e)^{c}$ & & 0.64 & 0.003 & 0.67 & 0.64 \\
\hline Shire-specific trends & no & no & yes & no & no \\
\hline$\chi^{2}$ test $(p \text {-value })^{d}$ & & & 0.033 & & \\
\hline Observations & 127 & 127 & 127 & 141 & 141 \\
\hline Boroughs & 55 & 55 & 55 & 69 & 69 \\
\hline
\end{tabular}

Notes: $\mathrm{Z}$ statistics in brackets (robust to arbitrary heteroskedasticity, except in (12)); * significant at $10 \%$; ** significant at 5\%; ${ }^{* * *}$ significant at $1 \%$; a) Regressions (11) and (12) include a constant; b) $\chi^{2}$ test: The null is that all regional fixed effects are $0 ; c) \chi^{2}$ test: The null is that all time fixed effects are $0 ;$ d) $\chi^{2}$ test: The null is that all shire-specific trends are $0 ;$ e) Turning point $=-\hat{\alpha}_{1} / 2 \hat{\alpha}_{2}$. 
Table 6: Results from IV estimation.

\begin{tabular}{|c|c|c|c|c|c|c|c|c|}
\hline & (11) & $(12)$ & (13) & (14) & $(15)$ & (16) & $(17)$ & $(18)$ \\
\hline Stage & $2^{\text {nd }}$ & $2^{\text {nd }}$ & $1^{\text {st }}$ & $1^{\mathrm{st}}$ & $2^{\text {nd }}$ & $2^{\text {nd }}$ & $1^{\mathrm{st}}$ & $1^{\mathrm{st}}$ \\
\hline Dependent variable ${ }^{a}$ & Spending & $\begin{array}{c}\text { Borrowed } \\
\text { funds }\end{array}$ & Franchise & $\begin{array}{c}\text { Franchise } \\
\text { squared }\end{array}$ & Spending & $\begin{array}{c}\text { Borrowed } \\
\text { funds }\end{array}$ & Franchise & $\begin{array}{c}\text { Franchise } \\
\text { squared }\end{array}$ \\
\hline \multirow[t]{2}{*}{$\begin{array}{l}\text { Franchise } \\
\text { (instrumented) }\end{array}$} & $-80.7^{* *}$ & $-141.7^{*}$ & & & $-72.1 * * *$ & $-101.8^{*}$ & & \\
\hline & {$[2.37]$} & {$[1.67]$} & & & {$[3.04]$} & {$[1.73]$} & & \\
\hline \multirow[t]{2}{*}{$\begin{array}{l}\text { Franchise squared } \\
\text { (instrumented) }\end{array}$} & $0.93 * *$ & $1.67 *$ & & & $0.95^{* * *}$ & $1.52 * *$ & & \\
\hline & {$[2.50]$} & {$[1.72]$} & & & {$[3.54]$} & [1.99] & & \\
\hline \multirow[t]{2}{*}{ Franchise lagged } & & & $1.18 * * *$ & $132.2 * * *$ & & & $1.10 * * *$ & $150.6^{* * *}$ \\
\hline & & & {$[3.88]$} & [3.99] & & & {$[2.93]$} & [3.94] \\
\hline \multirow[t]{2}{*}{$\begin{array}{l}\text { Franchise squared } \\
\text { lagged }\end{array}$} & & & $-0.02 * * *$ & $-1.85 * * *$ & & & $-0.016^{* * *}$ & $-2.02 * * *$ \\
\hline & & & {$[5.33]$} & {$[5.21]$} & & & {$[3.87]$} & {$[4.62]$} \\
\hline \multirow[t]{2}{*}{ Reform dummy 1869} & & & $17.01 * * *$ & $449.8^{* * *}$ & & & $17.5^{* * *}$ & $373.3 * * *$ \\
\hline & & & {$[9.54]$} & {$[8.36]$} & & & {$[3.73]$} & \begin{tabular}{|l}
{$[2.75]$} \\
\end{tabular} \\
\hline \multirow[t]{2}{*}{ Reform dummy 1882} & & & $32.95 * * *$ & $726.4 * * *$ & & & $32.7 * *$ & 754.6 \\
\hline & & & {$[8.56]$} & {$[5.47]$} & & & {$[2.08]$} & {$[1.58]$} \\
\hline \multirow[t]{2}{*}{ Relative wealth } & & & 0.56 & $109.1 *$ & & & 0.70 & 74.2 \\
\hline & & & {$[1.08]$} & {$[1.89]$} & & & {$[0.72]$} & {$[0.74]$} \\
\hline \multirow[t]{2}{*}{ Relative tax base } & & & $0.418 * *$ & 21.57 & & & 0.56 & 41.6 \\
\hline & & & {$[2.26]$} & {$[0.83]$} & & & {$[1.50]$} & {$[1.12]$} \\
\hline \multirow[t]{2}{*}{$\begin{array}{l}\text { Industrial } \\
\text { employment }\end{array}$} & $27.2 * *$ & $76.9 * *$ & 0.27 & 4.84 & & & & \\
\hline & {$[2.23]$} & {$[2.57]$} & {$[0.73]$} & {$[0.11]$} & & & & \\
\hline \multirow[t]{2}{*}{ Accumulated debt } & $0.18 * * *$ & $0.23 * *$ & $-0.002 * *$ & $-0.24 *$ & $0.22 * * *$ & $0.35 * * *$ & -0.002 & $-0.26^{* *}$ \\
\hline & {$[3.50]$} & {$[2.41]$} & {$[2.41]$} & {$[1.93]$} & {$[6.04]$} & {$[3.83]$} & {$[1.52]$} & {$[2.10]$} \\
\hline Turning point $^{\mathrm{b}}$ & 43.4 & 42.2 & & & 37.9 & 33.4 & & \\
\hline $\begin{array}{l}\text { Hansen J Test (p- } \\
\text { value) }^{\mathrm{c}}\end{array}$ & 0.46 & 0.68 & & & 0.82 & 0.93 & & \\
\hline \begin{tabular}{|l} 
F test on all \\
instruments
\end{tabular} & & & 23.9 & 15.1 & & & 9.3 & 5.8 \\
\hline$p$-value ${ }^{d}$ & & & 0.00 & 0.00 & & & 0.00 & 0.00 \\
\hline Partial $\mathrm{R}^{2}$ & & & 78 & 74 & & & 61 & 58 \\
\hline Shea partial $\mathrm{R}^{2}$ & & & 25 & 24 & & & 32 & 35 \\
\hline Region-specific trends & no & no & no & no & yes & yes & yes & yes \\
\hline \begin{tabular}{|l|} 
Observations \\
\end{tabular} & 77 & 77 & 77 & 77 & 77 & 77 & 77 & 77 \\
\hline Boroughs & 35 & 35 & 35 & 35 & 35 & 35 & 35 & 35 \\
\hline
\end{tabular}

Notes: Z statistics in brackets (robust to arbitrary heteroskedasticity and arbitrary autocorrelation); ${ }^{*}$ significant at $10 \%$; ** significant at 5\%; *** significant at 1\%; a) All regressions include borough fixed effects; b) Turning point $=$ $-\hat{\alpha}_{1} / 2 \hat{\alpha}_{2}$; c) The joint null hypothesis is that the extra instruments are valid; $\left.d\right) p$-value for test that all instruments are insignificant. The set of instruments is: franchise lagged, franchise squared lagged, reform dummy 1869, reform dummy 1882, relative wealth, and relative tax base. 
Table A1: Descriptive statistics

\begin{tabular}{|c|c|c|c|c|c|}
\hline 1868 & Obs & mean & st. dev. & $\min$ & $\max$ \\
\hline Franchise $^{\mathrm{a}}$ & 63 & 35.6 & 14.1 & 11.5 & 81.9 \\
\hline $\begin{array}{l}\text { Spending on urban } \\
\text { amenities per }(1000) \text { capita }\end{array}$ & 68 & 398.6 & 355.9 & 0 & 2216.1 \\
\hline $\begin{array}{l}\text { Borrowed funds per (1000) } \\
\text { capita }\end{array}$ & 68 & 189.3 & 319.6 & 0 & 1931.6 \\
\hline Population & 71 & 56761 & 62547 & 6887 & 350575 \\
\hline Industrial employment & 67 & 36.9 & 11.1 & 17.3 & 63.5 \\
\hline Rateable value & 58 & 1731.7 & 577.6 & 700.8 & 3777.7 \\
\hline Population density & 67 & 558.8 & 127.5 & 402.1 & 1184.8 \\
\hline Accumulated debt & 68 & 1775.5 & 2150.5 & 0 & 14820.7 \\
\hline Relative wealth & 71 & 38.9 & 15.2 & 14.8 & 63.8 \\
\hline Relative tax base & 67 & 58.4 & 15.9 & 17.9 & 88.1 \\
\hline 1871 & Obs & mean & st. dev. & $\min$ & Max \\
\hline Franchise & 73 & 56.9 & 12.9 & 28.2 & 81.9 \\
\hline $\begin{array}{l}\text { Spending on urban } \\
\text { amenities per }(1000) \text { capita }\end{array}$ & 74 & 453.2 & 451.6 & 27.7 & 2378.6 \\
\hline $\begin{array}{l}\text { Borrowed funds per (1000) } \\
\text { capita }\end{array}$ & 74 & 284.7 & 550.1 & 0 & 3626.5 \\
\hline Population & 74 & 67896 & 84379 & 6915 & 493405 \\
\hline Industrial employment & 70 & 36.4 & 10.8 & 16.7 & 61.9 \\
\hline Rateable value & 64 & 1705.3 & 599.2 & 699.1 & 3532.8 \\
\hline Population density & 73 & 557.3 & 122.3 & 385 & 1176.8 \\
\hline Accumulated debt & 74 & 2477.4 & 2648.6 & 0 & 13751.5 \\
\hline Relative wealth & 73 & 39.1 & 16.5 & 7.1 & 64.1 \\
\hline Relative tax base & 70 & 59.4 & 15.8 & 20.1 & 89.4 \\
\hline 1886 & Obs & mean & st. dev & $\min$ & Max \\
\hline Franchise $^{\mathrm{b}}$ & 75 & 64.2 & 10.8 & 33 & 86.7 \\
\hline $\begin{array}{l}\text { Spending on urban } \\
\text { amenities per }(1000) \text { capita }\end{array}$ & 75 & 887.4 & 779.1 & 90.5 & 5915.1 \\
\hline $\begin{array}{l}\text { Borrowed funds per (1000) } \\
\text { capita }\end{array}$ & 75 & 410.2 & 708.0 & 0 & 5026.2 \\
\hline Population & 75 & 87164.4 & 98386 & 7719 & 538685 \\
\hline Industrial employment & 30 & 34.7 & 11.5 & 7.3 & 55.8 \\
\hline Rateable value & 75 & 1939.5 & 900.5 & 276.9 & 6573.8 \\
\hline Population density & 75 & 547.3 & 108.7 & 430.7 & 1097.6 \\
\hline Accumulated debt & 75 & 6113.6 & 5236.2 & 148.1 & 21340.9 \\
\hline Relative wealth & 74 & 44.4 & 14.6 & 21.4 & 65.9 \\
\hline Relative tax base & 30 & 64.9 & 12.1 & 24.7 & 83.8 \\
\hline
\end{tabular}

Notes: a) the franchise refers to 1865 ; b) the franchise refers to 1884 . 
Table B1: Robustness checks I.

\begin{tabular}{|c|c|c|c|c|c|c|c|c|c|c|c|c|c|}
\hline & (1) & (2) & (3) & (4) & (5) & (6) & (7) & (8) & (9) & $(10)$ & (11) & (12) & (13) \\
\hline Dependent variable $^{d}$ & $\mathrm{~S}$ & $\mathrm{~B}$ & $\mathrm{~S}$ & $\mathrm{~B}$ & $\mathrm{~S}$ & $\mathrm{~B}$ & $\mathrm{~S}$ & $\mathrm{~B}$ & $\mathrm{~S}$ & $\mathrm{~B}$ & $\mathrm{~S}$ & $\mathrm{~B}$ & $\mathrm{~B}$ \\
\hline Robustness check & $\begin{array}{c}\text { New } \\
\text { Variable }\end{array}$ & $\begin{array}{c}\text { New } \\
\text { variable }\end{array}$ & $\begin{array}{c}\text { new } \\
\text { variable }\end{array}$ & $\begin{array}{c}\text { New } \\
\text { Variable }\end{array}$ & $\begin{array}{l}\text { Borough } \\
\text { specific } \\
\text { trend }\end{array}$ & $\begin{array}{l}\text { Borough } \\
\text { specific } \\
\text { trend }\end{array}$ & $\begin{array}{l}\text { Fiscal } \\
\text { lags }\end{array}$ & $\begin{array}{l}\text { Fiscal } \\
\text { lags }\end{array}$ & $\begin{array}{c}\text { Balan- } \\
\text { ced } \\
\text { panel }\end{array}$ & $\begin{array}{c}\text { Balan- } \\
\text { ced } \\
\text { panel }\end{array}$ & $G$ to $S^{c}$ & $G$ to $S^{c}$ & $G$ to $S^{c}$ \\
\hline \multirow[t]{2}{*}{ Franchise } & $-27.3^{*}$ & $-41.8^{*}$ & $-24.5^{\star}$ & $-42.9 *$ & $-61.2^{\star \star \star}$ & $-156.9 * \star \star$ & $-50.8^{*}$ & -37.1 & $-54.7^{* \star \star}$ & $-98.0 * \star \star$ & $-60.0^{* * *}$ & $-41.8^{* *}$ & $-49.2^{\star \star \star}$ \\
\hline & {$[1.67]$} & [1.65] & [1.68] & {$[1.76]$} & {$[4.04]$} & {$[8.52]$} & [1.65] & [1.57] & {$[2.85]$} & [2.59] & {$[4.18]$} & [2.39] & [2.58] \\
\hline \multirow[t]{2}{*}{ Franchise squared } & $0.37^{*}$ & $0.51^{*}$ & $0.34^{\star *}$ & $0.54^{*}$ & $0.87^{\star \star \star}$ & $1.9 * \star \star$ & $0.76^{* \star}$ & $0.57^{\star \star}$ & $0.72^{\star \star \star}$ & $1.17^{\star \star \star}$ & $0.74^{\star \star \star}$ & $0.52^{\star \star \star}$ & $0.55^{\star \star *}$ \\
\hline & [1.92] & {$[1.77]$} & {$[2.00]$} & [1.92] & {$[5.40]$} & [9.83] & {$[2.24]$} & {$[2.27]$} & {$[3.49]$} & {$[2.77]$} & {$[5.31]$} & {$[3.01]$} & [3.01] \\
\hline \multirow[t]{2}{*}{ Population } & -0.003 & 0.003 & -0.001 & 0.003 & 0.02 & $0.12^{\star \star \star}$ & 0.046 & 0.043 & -0.002 & 0.011 & & & \\
\hline & {$[0.57]$} & {$[0.55]$} & {$[0.11]$} & {$[0.43]$} & [1.08] & [5.62] & [1.60] & [1.48] & {$[0.35]$} & [1.25] & & & \\
\hline \multirow[t]{2}{*}{ Industrial employment } & -6.5 & 16.2 & -6.2 & 23.5 & $-104.6^{\star \star \star}$ & $-134.0^{\star \star \star}$ & -43.5 & -45.5 & -13.9 & 19.5 & $-59.8^{\star \star \star}$ & & \\
\hline & [0.31] & [0.61] & {$[0.30]$} & {$[0.91]$} & [2.99] & [3.15] & [1.20] & [1.16] & {$[0.76]$} & {$[0.72]$} & {$[2.60]$} & & \\
\hline \multirow[t]{2}{*}{ Rateable value } & 0.02 & 0.13 & -0.04 & 0.32 & $0.82^{\star *}$ & $1.11^{* *}$ & $0.89 *$ & $0.87^{*}$ & 0.098 & 0.887 & $0.57^{* *}$ & & $0.13^{* *}$ \\
\hline & {$[0.07]$} & [0.31] & {$[0.16]$} & {$[0.64]$} & [1.99] & [2.22] & [1.65] & [1.78] & {$[0.34]$} & {$[1.42]$} & {$[2.26]$} & & {$[2.07]$} \\
\hline \multirow[t]{2}{*}{ Population density } & -3.9 & -7.6 & -5.2 & -8.6 & 16.5 & 13.8 & $-12.9^{*}$ & -7.9 & -7.785 & -11.792 & & & \\
\hline & [0.95] & [1.52] & {$[1.24]$} & {$[1.61]$} & [1.45] & {$[1.00]$} & {$[1.69]$} & [1.09] & [1.52] & [1.52] & & & \\
\hline \multirow[t]{2}{*}{ Accumulated debt } & $0.25^{\star \star \star}$ & $0.28^{\star \star \star}$ & $0.23^{\star \star *}$ & $0.26^{\star \star}$ & $0.67^{*}$ & 0.31 & -0.20 & -0.39 & $0.736^{\star \star \star}$ & 0.14 & $0.27^{\star \star \star}$ & & $0.13^{* *}$ \\
\hline & [3.97] & [2.88] & [3.62] & {$[2.48]$} & {$[1.67]$} & [0.63] & {$[0.82]$} & [1.55] & [3.78] & {$[0.40]$} & [4.38] & & {$[2.05]$} \\
\hline \multirow[t]{2}{*}{$\begin{array}{l}\text { Budget share of rents } \\
\text { and profits }\end{array}$} & 2.05 & -10.6 & & & & & & & & & & & \\
\hline & {$[0.38]$} & {$[1.42]$} & & & & & & & & & & & \\
\hline \multirow[t]{2}{*}{ Growth in housing stock } & & & $6.2^{*}$ & 4.3 & & & & & & & & & \\
\hline & & & {$[1.92]$} & [0.95] & & & & & & & & & \\
\hline Turning point $\left(-\hat{\alpha}_{1} / 2 \hat{\alpha}_{2}\right)$ & 36.9 & 41 & 36 & 39.7 & 35.2 & 41.3 & 33.4 & 32.5 & 38.1 & 41.9 & 40.5 & 40.1 & 44.7 \\
\hline Time fixed effects & yes & yes & yes & Yes & yes & yes & yes & yes & yes & yes & yes & yes & yes \\
\hline$\chi^{2}$ test $(p-\text { value })^{b}$ & 0.86 & 0.78 & 0.6 & 0.67 & 0.01 & 0.03 & 0.11 & 0.12 & 0.01 & 0.07 & 0.001 & 0.18 & 0.67 \\
\hline Shire-specific trends & no & no & no & no & no & no & no & no & no & no & yes & no & yes \\
\hline Borough-specific trends & no & no & no & no & yes & yes & no & no & no & no & no & no & no \\
\hline Observations & 127 & 127 & 127 & 127 & 127 & 127 & 127 & 127 & 48 & 48 & 127 & 127 & 210 \\
\hline Boroughs & 55 & 55 & 55 & 55 & 55 & 55 & 55 & 55 & 16 & 16 & 55 & 55 & 74 \\
\hline
\end{tabular}

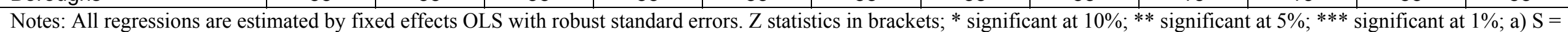

spending on urban amenities per (1000) capita, B = borrowed funds per (1000) capita; b) $\chi^{2}$ test: The null is that all fixed time effects are 0 ; c) general-to-specific. 
Table B2: Robustness checks II.

\begin{tabular}{|c|c|c|c|c|c|c|c|c|c|c|c|c|c|c|c|}
\hline & (14) & (15) & (16) & (17) & (18) & (19) & (20) & (21) & (22) & (23) & (24) & (25) & (26) & (27) & (28) \\
\hline Dependent variable ${ }^{a}$ & $\mathrm{~s}$ & $\mathrm{~s}$ & B & B & $\mathrm{s}$ & $\mathrm{s}$ & B & B & $\mathrm{s}$ & $\mathrm{s}$ & B & $\mathrm{s}$ & B & $\mathrm{s}$ & B \\
\hline Estimation method ${ }^{b}$ & $\mathrm{FE}$ & FE & FE & FE & FE & $\mathrm{FE}$ & $\mathrm{FE}$ & FE & $\mathrm{RE}$ & $\mathrm{RE}$ & $\mathrm{RE}$ & $\mathrm{BE}$ & $\mathrm{BE}$ & Tobit & Tobit \\
\hline Robustness check & $\begin{array}{c}\text { Cluster } \\
\text { town }\end{array}$ & $\begin{array}{c}\text { Cluster } \\
\text { town }\end{array}$ & $\begin{array}{c}\text { Cluster } \\
\text { town }\end{array}$ & $\begin{array}{c}\text { Cluster } \\
\text { town }\end{array}$ & $\begin{array}{c}\mathrm{AR} \\
\text { robust }\end{array}$ & $\begin{array}{c}\mathrm{AR} \\
\text { robust }\end{array}$ & $\begin{array}{c}\mathrm{AR} \\
\text { robust }\end{array}$ & $\begin{array}{c}\mathrm{AR} \\
\text { robust }\end{array}$ & & & & & & $\begin{array}{c}\text { Corner } \\
\text { solution }\end{array}$ & $\begin{array}{c}\text { Corner } \\
\text { solution }\end{array}$ \\
\hline \multirow[t]{2}{*}{ Franchise } & $-28.0^{*}$ & -26.8 & $-40.0^{*}$ & $-44.5^{\star}$ & $-28.0^{*}$ & $-26.8^{\star}$ & $-40.0^{*}$ & $-44.5^{\star}$ & $-17.9^{*}$ & -15.9 & $-31.9^{\star \star \star \star}$ & -15.1 & -17.9 & $-26.7^{\star \star \star}$ & $-57.1^{* \star *}$ \\
\hline & {$[1.88]$} & [1.57] & [1.77] & [1.68] & [1.95] & [1.65] & [1.78] & {$[1.71]$} & [1.89] & {$[1.52]$} & {$[2.70]$} & {$[0.78]$} & [0.74] & {$[2.89]$} & {$[3.45]$} \\
\hline \multirow[t]{2}{*}{ Franchise squared } & $0.35^{\star *}$ & $0.36^{\star}$ & $0.50^{*}$ & $0.56^{*}$ & $0.35^{\star \star}$ & $0.36^{*}$ & $0.50^{*}$ & $0.56^{*}$ & $0.26^{\star \star \star}$ & $0.23^{\star \star}$ & $0.40^{\star \star \star *}$ & 0.21 & 0.21 & $0.37^{\star \star \star \star}$ & $0.75^{\star \star \star}$ \\
\hline & [2.00] & {$[1.80]$} & [1.83] & [1.80] & [2.08] & [1.89] & [1.86] & [1.87] & [2.63] & {$[2.22]$} & {$[3.46]$} & [1.18] & {$[0.97]$} & {$[4.00]$} & [4.49] \\
\hline \multirow[t]{2}{*}{ Population } & -0.004 & -0.003 & -0.004 & 0.001 & -0.004 & -0.003 & -0.004 & 0.001 & -0.001 & $-0.001^{\star}$ & -0.001 & 0.0002 & $0.003^{\star \star \star}$ & -0.002 & 0.004 \\
\hline & [1.21] & {$[0.65]$} & [0.61] & [0.22] & [0.90] & {$[0.49]$} & [0.63] & {$[0.22]$} & [1.59] & {$[1.79]$} & [1.07] & {$[0.32]$} & {$[3.08]$} & {$[0.47]$} & {$[0.66]$} \\
\hline \multirow[t]{2}{*}{ Industrial employment } & -2.6 & -7.7 & $43.9 * \star$ & 22.3 & -2.6 & -7.7 & $43.9^{\star \star}$ & 22.3 & $11.6^{\star \star \star}$ & $12.7^{\star \star \star}$ & $12.7^{\star \star \star}$ & $16.2^{\star \star \star}$ & $9.9^{\star}$ & $-30.1^{*}$ & 1.63 \\
\hline & {$[0.20]$} & {$[0.37]$} & [2.41] & [0.81] & {$[0.17]$} & [0.37] & [2.33] & {$[0.85]$} & [3.47] & {$[3.86]$} & {$[3.45]$} & [3.79] & [1.88] & [1.92] & {$[0.06]$} \\
\hline \multirow[t]{2}{*}{ Rateable value } & -0.0001 & -0.02 & 0.30 & 0.33 & -0.0001 & -0.02 & 0.30 & 0.33 & $0.23^{\star \star \star}$ & $0.23^{\star \star \star}$ & $0.14^{\star}$ & $0.20^{\star \star}$ & 0.09 & -0.20 & 0.12 \\
\hline & {$[0.00]$} & [0.13] & {$[0.76]$} & {$[0.77]$} & {$[0.00]$} & [0.08] & [0.60] & [0.65] & {$[3.16]$} & {$[3.45]$} & [1.91] & [2.39] & {$[0.89]$} & [1.13] & [0.42] \\
\hline \multirow[t]{2}{*}{ Population density } & -3.3 & -3.9 & -4.7 & -7.7 & -3.2 & -3.9 & -4.7 & -7.7 & -0.4 & -0.4 & -0.2 & -0.20 & -0.37 & -0.52 & -1.99 \\
\hline & {$[0.72]$} & {$[0.95]$} & {$[0.95]$} & [1.47] & {$[0.75]$} & {$[0.95]$} & [0.98] & [1.51] & [1.22] & [1.30] & [0.51] & {$[0.37]$} & [0.57] & {$[0.16]$} & {$[0.34]$} \\
\hline \multirow[t]{2}{*}{ Accumulated debt } & $0.26^{\star \star \star}$ & $0.25^{\star \star \star}$ & $0.27^{\star \star \star}$ & $0.28^{\star \star \star}$ & $0.26^{\star \star \star}$ & $0.25^{\star \star \star}$ & $0.27^{\star \star \star}$ & $0.28^{\star \star \star}$ & $0.26^{\star \star \star}$ & $0.26^{\star \star \star}$ & $0.38^{\star \star \star}$ & $0.17^{\star \star \star}$ & -0.07 & $0.30^{\star \star \star}$ & $0.33^{\star \star \star}$ \\
\hline & [4.30] & {$[3.97]$} & {$[2.87]$} & {$[2.67]$} & [4.04] & {$[3.84]$} & [2.70] & {$[2.60]$} & {$[4.50]$} & {$[4.31]$} & {$[5.60]$} & [3.22] & [1.01] & {$[4.45]$} & [2.95] \\
\hline Hausman test (p-value) & & & & & & & & & 0.3 & 0.6 & 0.93 & & & & \\
\hline Turning point $\left(-\hat{\alpha}_{1} / 2 \hat{\alpha}_{2}\right)$ & 40 & n.a. & 40 & 39.7 & 40 & 40 & 40 & 39.7 & 34.4 & n.a & 39.9 & n.a. & n.a. & 36.1 & 38.1 \\
\hline Time fixed effects & no & yes & no & yes & no & yes & no & yes & no & yes & yes & yes & yes & yes & yes \\
\hline$\chi^{2}$ test $^{c}(p-$-value $)$ & & 0.64 & & 0.88 & & 0.65 & & 0.88 & & 0.81 & 0.01 & 0.04 & 0.63 & 0.16 & 0.03 \\
\hline Observations & 127 & 127 & 127 & 127 & 127 & 127 & 127 & 127 & 127 & 127 & 127 & 141 & 141 & 127 & 127 \\
\hline Boroughs & 55 & 55 & 55 & 55 & 55 & 55 & 55 & 55 & 55 & 55 & 55 & 69 & 69 & 55 & 55 \\
\hline
\end{tabular}

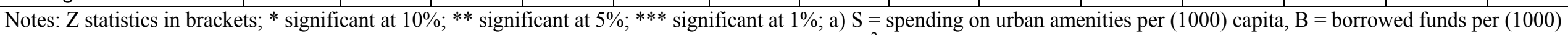
capita; b) FE = fixed effects estimator; $\mathrm{RE}=$ random effects estimator; $\mathrm{BE}=$ between estimator; $\mathrm{c}) \chi^{2}$ test: The null is that all fixed time effects are 0 . 
